Article

\title{
Optimization through Response Surface Methodology of a Reactor Producing Methanol by the Hydrogenation of Carbon Dioxide
}

\author{
Grazia Leonzio \\ Department of Industrial and Information Engineering and Economics, University of L'Aquila, \\ Via Giovanni Gronchi 18,67100 L'Aquila, Italy; grazia.leonzio@graduate.univaq.it
}

Received: 17 September 2017; Accepted: 10 October 2017; Published: 23 October 2017

\begin{abstract}
Carbon dioxide conversion and utilization is gaining significant attention worldwide, not only because carbon dioxide has an impact on global climate change, but also because it provides a source for potential fuels and chemicals. Methanol is an important fuel that can be obtained by the hydrogenation of carbon dioxide. In this research, the modeling of a reactor to produce methanol using carbon dioxide and hydrogen is carried out by way of an ANOVA and a central composite design. Reaction temperature, reaction pressure, $\mathrm{H}_{2} / \mathrm{CO}_{2}$ ratio, and recycling are the chosen factors, while the methanol production and the reactor volume are the studied responses. Results show that the interaction $A C$ is common between the two responses and allows improvement of the productivity in reducing the volume. A mathematical model for methanol production and reactor volume is obtained with significant factors. A central composite design is used to optimize the process. Results show that a higher productivity is obtained with temperature, $\mathrm{CO}_{2} / \mathrm{H}_{2}$ ratio, and recycle factors at higher, lower, and higher levels, respectively. The methanol production is equal to $33,540 \mathrm{~kg} / \mathrm{h}$, while the reactor volume is $6 \mathrm{~m}^{3}$. Future research should investigate the economic analysis of the process in order to improve productivity with lower costs.
\end{abstract}

Keywords: methanol production; ANOVA analysis; response surface methodology; process simulation; carbon capture and utilization; optimization

\section{Introduction}

With the rapid development of the world's society and economy, especially in developing countries, the growing needs for energy supply are becoming devastating. Global energy demand is expected to double by 2050 [1]. More than $80 \%$ of global energy demand is still satisfied by fossil fuels due to their abundance and availability [2]. However, the world fossil fuels are depleting and produce different environmental problems, suggesting that alternative solutions are needed.

For these reasons, renewable energies (RES) are suggested as an alternative to traditional fossil fuels, and significant progress has been achieved. The need to find clean and sustainable energy is a critical factor for society [3].

In this context, power-to-liquid (PtL) systems seem to represent an efficient solution for future energy scenarios: a PtL technology concerns a process that is able to absorb energy (overproduction of RES on the grid), converting and storing that energy into liquid fuels through the use of carbon dioxide as a reagent. This system is an effective way to moderate the intermittency of renewable energy in order to stabilize the electrical grid. In addition, the conversion of carbon dioxide into fuels allows the recycling of carbon dioxide and the reduction of greenhouse gas (GHG) emissions.

Processes based on methanol synthesis have received significant attention over the past decade. Carbon dioxide and hydrogen are used as raw materials according to hydrogenation catalytic reaction. In recent years, several efforts have been made to develop efficient $\mathrm{CO}_{2}$ utilization technologies, and 
the more attractive processes are the hydrogenation of $\mathrm{CO}_{2}$ and the reforming of $\mathrm{CO}_{2}$ with $\mathrm{CH}_{4}$ [4-6]. Sources of carbon dioxide can be: power plants, air, ammonia plants, anaerobic digestion plants, process industries like cement, iron, and steel, aluminum, pulp and paper, and refineries from which it is produced by way of carbon capture and utilization (CCU) processes [7]. Waste is then recovered and enhanced to produce chemical compounds. Hydrogen, instead, can be produced by the electrolysis of water using renewable energies such as solar or wind energy. It may be produced through the alkaline or proton exchange membrane electrolysis (PEM), while the solid oxide electrolyser cells (SOECs) are currently less developed [8]. Hydrogen can also be obtained by coke oven gas (COG) from steel works, syngas, methane steam reforming, chlorine alkali, and petrochemical plants [9]. An innovative technology allows the production of hydrogen by photocatalytic water splitting [10]. A catalytic reaction producing methanol takes place in the ranges of temperature and pressure equal to $423-523 \mathrm{~K}$ and $50-100$ bar, respectively, on $\mathrm{CuO} / \mathrm{ZnO} / \mathrm{Al}_{2} \mathrm{O}_{3}$ as catalyst [11,12].

It is evident that the use of renewable resources to substitute fossil fuels is one of the technological options to mitigate GHG emissions [13]. Using this in relation to methanol production is then a green process, with lower environmental impacts.

Other routes can be used for the production of methanol, such as the dry reformation of methane and carbon dioxide into syngas that is converted into methanol through the Fischer-Tropsch reaction [14,15], the hydrogenation of syngas [16], the co-electrolysis of carbon dioxide and water $[17,18]$, or the photocatalytic reaction of carbon dioxide and water $[19,20]$. Additionally, as an alternative to carbon dioxide, other raw materials can be used to produce methanol as natural gas through a reforming reaction or as coal and biomass via gasification [21]. Currently, methanol is predominantly produced from natural gas via steam reforming or from coal via gasification on an industrial scale [22].

Methanol is a key chemical intermediate for numerous commodities: dimethyl ether, methylamines, chloromethanes, solvents, propylene, olefins, formaldehyde, acetic acid, methyl methacrylate, gasoline/fuels $[13,23,24]$. Methanol-to-olefins (MTO) and methanol-to-propylene (MTP) demand has increased in recent years, rising from 6\% of end use demand in 2011 to $22 \%$ by 2016, especially in China [25]. Other uses of methanol include wastewater de-nitrification, the hydrogen carrier for fuel cells and the transesterification of vegetable oils for biodiesel production and electricity generation [26,27]. Methanol can then be used from energy uses to chemical uses [28,29]. With a high-octane number, methanol ensures good antiknock performance, in addition to high volatility, denser fuel-air charge, and excellent lean burn properties [30]. The current annual consumption of methanol is over 60 million metric tons globally, and it will grow [31]. In 2030, meeting the European yearly demand will require $41-76 \mathrm{MtCO}_{2}$ /year, meaning that $16-31 \mathrm{MtCO}_{2}$ /year of $\mathrm{CO}_{2}$ will not be emitted, because through the use of CCU systems $28-52 \mathrm{Mt} \mathrm{MeOH} /$ year will be produced [32].

The production of methanol via the hydrogenation of carbon dioxide and hydrogen is a mature technology, and the literature mainly covers the economic and technical aspects of its process. Pilot plants that use renewable hydrogen are in operation in Japan, Iceland (with a capacity of 4000 ton/year, constructed by Carbon Recycling International and operating since 2011), and Osaka (with a capacity of 100 ton/year) [11]. The catalytic hydrogenation of carbon dioxide has become technically competitive with the industrial production of methanol from syngas $[11,33,34]$, and shows great potential for large-scale applications and carbon dioxide consumption [35].

Bellotti et al. [22] analyzed a process for the production of methanol by capturing carbon dioxide from power plants and producing hydrogen from PEM electrolyzers. The power to process methanol is made possible by water electrolyzers and carbon capture systems, using amine solution and a methanol reactor. An economic feasibility study of the plant was carried out, taking into consideration three different sizes (4000, 10,000, 50,000 ton/year of $\mathrm{CH}_{3} \mathrm{OH}$ produced), using W-ECoMP software. A sensitivity analysis was also developed, varying methanol selling price, oxygen selling options for industrial applications, and the capital cost of PEM electrolyzers. Results show that the PEM 
electrolyzer affects more than $75 \%$ of total capital investment and a larger plant leads to higher capital investment but allows for a slower payback period.

Atsonios et al. [36] analyzed a process to produce methanol using carbon dioxide obtained by power plants or other intensive carbon emission industries (cement plant, steel industry) through mono-ethanolamine (MEA) absorption, while hydrogen is obtained by water electrolysis with alkaline electrolyzers. Different electric sources are considered: grids, thermal power plants, wind energies. An economic analysis of an $\mathrm{H}_{2}$ production scheme reveals that each of three main parameters for the determination of $\mathrm{H}_{2}$ cost (electrolyzer capital cost, electricity cost, and storage cost) can play a key role in the feasibility of the plant. Then, hydrogen production cost is the most significant factor influencing the economy of this methanol process. The total specific power consumption of the methanol plant was equal to $113.4 \mathrm{kWhe} / \mathrm{ton}_{\mathrm{MeOH}}$.

Rivera-Tinoco et al. [37] found a methanol cost of $891 € /$ ton for the PEM/methanol process and $5459 € /$ ton for the SOEC/methanol process. Promising reduction can be obtained by improving the electrolyzed system: its energy efficiency is a key parameter to decrease costs. On the other hand, research activities for high-temperature $\mathrm{CO}_{2}$ electrolysis are accelerating [38].

Perez-Fortes et al. [7] evaluated a techno-economic and environmental analysis for a process producing methanol from $\mathrm{H}_{2}$ and $\mathrm{CO}_{2}$ captured by power plants. In particular, the net reduction of $\mathrm{CO}_{2}$ emissions and production cost were evaluated in comparison with the conventional synthesis processes of $\mathrm{MeOH}$ in Europe. The evaluated plant produces $440 \mathrm{kton} /$ year of methanol, and its configuration is the result of a heat integration process. A simulation of the system was developed in ChemCad $6.3^{\circledR}$ software (Chemstation, Huston, Texas, USA). Results show that in order to have an economically feasible plant, the price of methanol should be around $800 € /$ ton, $\mathrm{H}_{2}$ costs should be around $1236 € /$ ton, or $\mathrm{CO}_{2}$ should have a value of around $222 € / \mathrm{t}$. Additionally, compared to traditional plants, the process has a lower capital cost but higher variable costs. Regarding an environmental analysis, the system allows the emission of 2 tons of carbon dioxide to be avoided for one ton of produced methanol.

Kiss et al. [9] developed a new process to produce methanol by the hydrogenation of carbon dioxide, using wet hydrogen available as a by-product in chlor-alkali production. The key feature of this novel process is the use of a stripping unit, where wet hydrogen (saturated with water) flows in counter-current with a condensed mixture of methanol-water resulting from flash separation after reaction. In this way, $\mathrm{CO}_{x}$ is removed by methanol-water mixture, allowing a complete recycling of $\mathrm{CO}_{2}$, also removing water from wet hydrogen (initially saturated with water) and thus avoiding a negative impact on reaction equilibrium conversion.

Atsonios et al. [39] developed a new membrane reactor with high selectivity either in methanol permeation or in water permeation. Methanol was produced according to the hydrogenation of carbon dioxide obtained by power plants while hydrogen was obtained by the electrolysis of water in alkaline cells. Results showed that the membrane did not influence thermal efficiency, but increased methanol yield. This allows the reduction of the recycling gas flow rate, leading to reduced reactor dimensions and investment costs.

Al-Kalbani et al. [31] compared two different processes to produce methanol using Aspen Hysys software: the hydrogenation of carbon dioxide for the first scheme and the co-electrolysis of water and carbon dioxide for the second scheme. Results show that a higher co-electrolysis temperature determines a lower energy demand compared to hydrogenation systems. The energy efficiency of co-electrolysis is equal to $41 \%$-almost double that of the hydrogenation processes. A heat integration is suggested by recovering heat from methanol reaction in order to produce electricity through a Rankine cycle.

Harp et al. [40] developed a process by integrating a methanol plant in a steelworks plant with a section for the capture of $\mathrm{CO}_{2}$ by power plant flue gas, a pressure swing adsorption (PSA) section for hydrogen separation from coke oven gas, and the use of the residual gas within the works gas grid, a water electrolysis section, a methanol synthesis section, and its distillation. Oxygen from water 
electrolysis replaced oxygen required for the blast furnace. In addition to PSA processes to recover hydrogen from COG, membranes are under development. In China, the first plant according to this scheme has been realized: with a purity above $99 \%$, a recovery rate of up to $90 \%$ is possible [41].

An integration between the methanol and biogas plant was developed by Pedersen and Schultz [42]: the biogas plant provided carbon dioxide for a hydrogenation reaction producing methanol. Hydrogen was obtained by water electrolysis. Additionally, methane recovered by the upgrading of biogas can be used with carbon dioxide to produce methanol through steam reforming reaction. In Matzen et al. [43], carbon dioxide was obtained by fermentation of ethanol, while wind energy was used for the electrolysis of water producing hydrogen. The energy efficiency of the process is comparable with others based on syngas.

A comparison of different processes to produce methanol was developed by Gai et al. [44], where co-electrolysis of $\mathrm{CO}_{2}$ and $\mathrm{H}_{2} \mathrm{O}$ with a F-T reactor, a photocatalytic reactor for $\mathrm{CO}_{2}$ and $\mathrm{H}_{2} \mathrm{O}$, and an electro-catalytic reactor for $\mathrm{CO}_{2}$ and $\mathrm{H}_{2} \mathrm{O}$ are analyzed. The overall NZCE (near-zero-carbon-emission) power plant using $\mathrm{CO}_{2}-\mathrm{CH}_{3} \mathrm{OH}$ circulation as the working medium was simulated and analyzed using Aspen Plus software. Results suggest that the energy consumption of methanol synthesis from $\mathrm{CO}_{2}$ and $\mathrm{H}_{2} \mathrm{O}$ through photo-catalysis is lower than other routes. The NZCE power plant can reduce $\mathrm{CO}_{2}$ emission of $3.8 \times 10^{6}$ ton/year, while supplying the electricity of $5.87 \times 10^{6} \mathrm{MWh} /$ year.

In this research, an ANOVA analysis was developed for the reactor producing methanol by the hydrogenation of carbon dioxide. Hydrogen was obtained by water electrolysis using solar energy, while carbon dioxide was captured by fuel gas. Compared to other production methods, the water electrolysis has the advantages of wide availability, flexibility, and high product purity [31]. A similar work to those shown above is not present in literature regarding the design and economic analysis of plants that produce methanol. Reaction temperature, reaction pressure, $\mathrm{H}_{2} / \mathrm{CO}_{2}$ ratio, and the recycle of produced stream are the chosen factors in the factorial design. The methanol production and the reactor volume are the analyzed responses. In this way, it is possible to determine how to improve the methanol production reducing the reactor volume, as well as factors that are significant in the chosen responses. A central composite design (CCD) was also developed in order to find the optimal operating conditions of the process and a response surface plot for the methanol production, with a respective mathematical model. Modeling data for the two analyses were obtained from the simulation of the reactor in ChemCad $6.3^{\circledR}$ software. The reactor was modelled according to the kinetics of Graaf et al. [45] using $\mathrm{Cu} / \mathrm{ZnO} / \mathrm{Al}_{2} \mathrm{O}_{3}$ as catalyst. It is evident that the production of $\mathrm{MeOH}$ is especially attractive in emerging economies as a liquid fuel to replace conventional sources of energy. Additionally, CCU appears as a developing alternative, with an important potential to motivate carbon capture.

\section{Materials and Methods}

\subsection{Modeling of the Catalytic Reactor}

The reactor for the methanol production which is analyzed in this research was modelled in ChemCad $6.3^{\circledR}$ software using a kinetic reactor, as shown in Figure 1. It is an adiabatic ideal plug flow reactor using commercial $\mathrm{Cu} / \mathrm{ZnO} / \mathrm{Al}_{2} \mathrm{O}_{3}$ catalyst. This catalyst was studied by several authors [46,47] for the methanol production from $\mathrm{CO}_{2}$, although it is less efficient with supply of $\mathrm{CO}_{2}$ than $\mathrm{CO} / \mathrm{CO}_{2}$ [47]. The catalyst density is equal to $1775 \mathrm{~kg}$ cat $/ \mathrm{m}^{3}$ cat, the fixed bed porosity is 0.5 , the pellet diameter is $0.000055 \mathrm{~m}$, and the pellet height is $0.00003 \mathrm{~m}$ [12]. Copper acts as the main active component, $\mathrm{ZnO}$ acts as a supporter, and $\mathrm{Al}_{2} \mathrm{O}_{3}$ acts as a promoter.

Methanol is obtained from the hydrogenation of $\mathrm{CO}_{2}$ according to the following reactions (see Equations (1)-(3)):

$$
\mathrm{CO}_{2}+\mathrm{H}_{2} \leftrightarrow \mathrm{CO}+\mathrm{H}_{2} \mathrm{O} \Delta \mathrm{H}_{298}^{0}=41.2 \mathrm{~kJ} / \mathrm{mol}_{\mathrm{CO}_{2}}
$$




$$
\begin{gathered}
\mathrm{CO}+2 \times \mathrm{H}_{2} \leftrightarrow \mathrm{CH}_{3} \mathrm{OH} \Delta \mathrm{H}_{298}^{0}=-90.7 \mathrm{~kJ} / \mathrm{mol}_{\mathrm{CO}} \\
\mathrm{CO}_{2}+3 \times \mathrm{H}_{2} \leftrightarrow \mathrm{CH}_{3} \mathrm{OH}+\mathrm{H}_{2} \mathrm{O} \Delta \mathrm{H}_{298}^{0}=-49.5 \mathrm{~kJ} / \mathrm{mol}_{\mathrm{CO}_{2}}
\end{gathered}
$$

According the kinetics of Graaf et al. [45], reaction rates are expressed, respectively, by the following expressions (see Equations (4)-(6)) in $\mathrm{kmol} / \mathrm{kg}_{\text {cat }} \times \mathrm{s}$ :

$$
\begin{aligned}
& r_{1}=\frac{k_{2} \times K_{\mathrm{CO}_{2}} \times\left(p_{\mathrm{CO}_{2}} \times p_{\mathrm{H}_{2}}-\frac{p_{\mathrm{H}_{2} \mathrm{O}} \times p_{\mathrm{CO}}}{K_{\text {eq, }}}\right)}{\left(1+K_{\mathrm{CO}} \times p_{\mathrm{CO}}+K_{\mathrm{CO}_{2}} \times p_{\mathrm{CO}_{2}}\right) \times\left(p_{\mathrm{H}_{2}}^{\frac{1}{2}}+\frac{K_{\mathrm{H}_{2} \mathrm{O}}}{K_{\mathrm{H}_{2}}^{\frac{1}{2}} \times p_{\mathrm{H}_{2} \mathrm{O}}}\right)} \\
& r_{2}=\frac{k_{1} \times K_{\mathrm{CO}} \times\left(p_{\mathrm{CO}} \times p_{\mathrm{H}_{2}}^{\frac{3}{2}}-\frac{p_{\mathrm{CH}_{3} \mathrm{OH}}}{K_{e q, 1} \times \sqrt{p_{\mathrm{H}_{2}}}}\right)}{\left(1+K_{\mathrm{CO}} \times p_{\mathrm{CO}}+K_{\mathrm{CO}_{2}} \times p_{\mathrm{CO}_{2}}\right) \times\left(p_{\mathrm{H}_{2}}^{\frac{1}{2}}+\frac{K_{\mathrm{H}_{2} \mathrm{O}}}{K_{\mathrm{H}_{2}}^{\frac{1}{2}} \times p_{\mathrm{H}_{2} \mathrm{O}}}\right)} \\
& r_{3}=\frac{k_{3} \times K_{\mathrm{CO}_{2}} \times\left(p_{\mathrm{CO}_{2}} \times p_{\mathrm{H}_{2}}^{3 / 2}-\frac{p_{\mathrm{CH}_{3} \mathrm{OH}} \times p_{\mathrm{H}_{2} \mathrm{O}}}{K_{\text {eq,3 } 3} \times \sqrt{p_{\mathrm{H}_{2}}}}\right)}{\left(1+K_{\mathrm{CO}} \times p_{\mathrm{CO}}+K_{\mathrm{CO}_{2}} \times p_{\mathrm{CO}_{2}}\right) \times\left(p_{\mathrm{H}_{2}}^{\frac{1}{2}}+\frac{K_{\mathrm{H}_{2} \mathrm{O}}}{K_{\mathrm{H}_{2}}^{\frac{1}{2}} \times p_{\mathrm{H}_{2} \mathrm{O}}}\right)}
\end{aligned}
$$

where partial pressures $p_{i}$ are in bars and exponential factors $k_{1}, k_{2}, k_{3}$ have the following expression (see Equation (7)):

$$
k_{i}=A \times e^{\left(\frac{-E_{a}}{R \times T}\right)}
$$

where $E_{a}$ is the activation energy in $\mathrm{J} / \mathrm{mol}, R$ is the constant of universal gas equal to $8.314 \mathrm{~J} / \mathrm{mol} \mathrm{K}, T$ is the temperature in Kelvin and $A$ is a pre-exponential factor. Table 1 shows the values of activation energies and pre-exponential factors in the three relations.

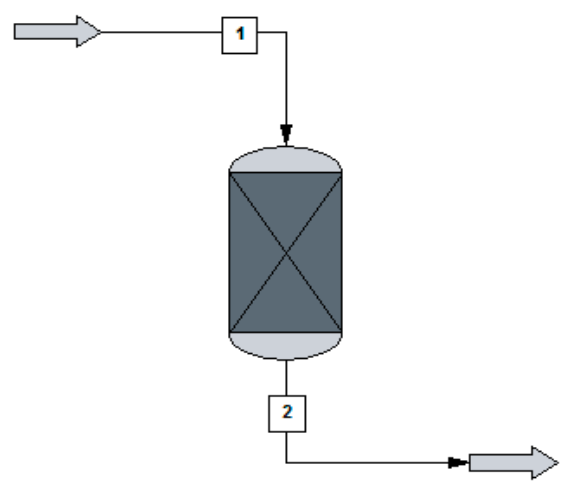

Figure 1. Methanol reactor used in ChemCad $6.3^{\circledR}$ environmental for the simulations $(1=$ inlet feed; $2=$ produced stream with the produced methanol).

Table 1. Pre-exponential factor $(A)$ and activation energy $\left(\mathrm{E}_{\mathrm{a}}\right)$ for reaction 1: $\mathrm{CO}+2 \mathrm{H}_{2} \leftrightarrow \mathrm{CH}_{3} \mathrm{OH}$, reaction 2: $\mathrm{CO}_{2}+\mathrm{H}_{2} \leftrightarrow \mathrm{CO}+\mathrm{H}_{2} \mathrm{O}$, reaction 3: $\mathrm{CO}_{2}+3 \mathrm{H}_{2} \leftrightarrow \mathrm{CH}_{3} \mathrm{OH}+\mathrm{H}_{2} \mathrm{O}$ involved in methanol synthesis.

\begin{tabular}{ccc}
\hline Reaction & $\boldsymbol{A}\left(\mathbf{s}^{-\mathbf{1}}\right)$ & $\mathrm{E}_{\mathbf{a}}(\mathrm{J} / \mathbf{m o l})$ \\
\hline 1 & $7.31 \times 10^{10}$ & $1.23 \times 10^{5}$ \\
2 & $2.90 \times 10^{7}$ & $1.10 \times 10^{5}$ \\
3 & $4.36 \times 10^{2}$ & $6.52 \times 10^{4}$ \\
\hline
\end{tabular}


The expression for thermodynamic equilibrium constant is as follows (see Equation (8)) [45]:

$$
\log _{10} K_{e q, i}=\frac{A}{T}+B
$$

where $A$ and $B$ are parameters and $T$ is temperature in Kelvin.

Table 2 shows the values of the parameters $A$ and $B$ for three reactions.

Table 2. Values of parameters $A$ and $B$ in the expression of equilibrium constant for reaction 1: $\mathrm{CO}+2 \mathrm{H}_{2} \leftrightarrow \mathrm{CH}_{3} \mathrm{OH}$, reaction 2: $\mathrm{CO}_{2}+\mathrm{H}_{2} \leftrightarrow \mathrm{CO}+\mathrm{H}_{2} \mathrm{O}$, reaction 3: $\mathrm{CO}_{2}+3 \mathrm{H}_{2} \leftrightarrow \mathrm{CH}_{3} \mathrm{OH}+\mathrm{H}_{2} \mathrm{O}$ involved in methanol synthesis.

\begin{tabular}{ccc}
\hline Reaction & $\boldsymbol{A}$ & $\boldsymbol{B}$ \\
\hline 1 & -2073 & 2.029 \\
2 & 5139 & -12.621 \\
3 & 3066 & -14.65 \\
\hline
\end{tabular}

In addition, for three reaction rates, these expressions are considered (see Equations (9)-(11)) [45]:

$$
\begin{gathered}
K_{\mathrm{CO}}=7.99 \times 10^{-7} \times e^{\left(\frac{581 \times 10^{4}}{R \times T}\right)} \\
K_{\mathrm{CO}_{2}}=1.2 \times 10^{-7} \times e^{\left(\frac{6.74 \times 10^{4}}{R \times T}\right)} \\
\frac{K_{\mathrm{H}_{2} \mathrm{O}}}{K_{\mathrm{H}_{2}}^{\frac{1}{2}}}=4.13 \times 10^{-11} \times e^{\left(-\frac{10.45 \times 10^{4}}{R \times T}\right)}
\end{gathered}
$$

where $T$ is the temperature in Kelvin and $R$ is the universal gas constant.

The kinetics of Graaf et al. [45] was explained by a dual-site Langmuir-Hinshelwood mechanism based on hydrogen adsorption and on three reactions: methanol formation from $\mathrm{CO}$, methanol formation from $\mathrm{CO}_{2}$, and water gas-shift reaction. Depending on which elementary reaction step is rate-controlling in each of these three reactions, 48 different kinetic models are possible. Based on $\chi^{2}$ statistic and consistency tests, the above-described model was obtained. In addition, the developed experiments supported the assumption of dissociative hydrogen adsorption. The above kinetic reaction provides a significantly better agreement with experimental results than kinetic models taken from recent literature. Graaf et al. [45] developed the model considering a spinning basket reactor at $15-50$ bar and $483-518 \mathrm{~K}$, and experimental evidence showed that methanol can be formed simultaneously from both $\mathrm{CO}$ and $\mathrm{CO}_{2}$.

Carbon dioxide conversion in the reaction was set equal to 30\% [48]. Temperature, pressure, and gas composition were set according to factorial design, as explained below. Generally, reaction pressure and temperature in methanol synthesis are between 50-100 bar and 473-573 K, respectively [49]. However, an inlet flowrate equal to $400 \mathrm{t} / \mathrm{h}$ was considered. Carbon dioxide was captured by fuel gas in a power plant with amine chemical absorption, while hydrogen was produced by the electrolysis of water using alkaline electrolysis. The alkaline $(\mathrm{KOH})$ electrolysis is the best available technology, as it is quite mature up to large-scale $\mathrm{H}_{2}$ production [50]. Additionally, the electrolysis method can produce pure hydrogen. Using solar energy, it is the best option for a suitable and non-fossil fuel-oriented hydrogen production. On the other hand, the chemical absorption technique with amine scrubbing is the most mature technology with the highest technology readiness level and has already been tested and implemented in large-scale applications [36]. The production of by-product was not considered in this model, and $\mathrm{CO}_{2}, \mathrm{CO}, \mathrm{H}_{2}$, and $\mathrm{H}_{2} \mathrm{O}$ were considered in the inlet gas composition.

For the simulation of the reactor, it is necessary to set an enthalpy model to determine energy balances and a global $\mathrm{K}$ model to calculate activity coefficients involved in equilibrium phases. 
Soave-Redlich-Kwong (SRK) Equation of State (EOS) was chosen since it is widely used in gas processing simulation due to its accuracy and simplicity [12,51]. Additionally, this equation is able to represent both liquid and vapor phases in conditions far from ideality, which is the case of this high-pressure process. The simulations were carried out in steady-state conditions.

\subsection{ANOVA Modeling}

For the methanol reactor, the estimation of main and interaction effects was developed by ANOVA analysis (analysis of variance); it was determined if effects and interactions among the investigated factors were significant with respect to experimental error $\left(\sigma_{\varepsilon}\right)$. Main factors were evaluated by Yates's algorithm through Excel 2016 software. Statistical significance was checked by F-value (Fischer variation ratio) and $p$-value (significant probability value). Model terms were selected or rejected based on probability value within $95 \%$ of confidence interval (or $5 \%$ significance level). In this research, $\sigma_{\varepsilon}$ was evaluated by means of the mean square (MS) of interactions that were not significant. A $2^{4}$ full factorial design with 16 simulations test was performed for this research [52]. A mathematical model could be obtained with significant factors and the quality of the model was assessed by coefficient of determination $R^{2}$. $R^{2}$ represents a pure correlation between measured and predicted values, and it is indicative of response variation explained by model. Then, in this statistic method all factor levels (process parameters) are fully changed so that it is possible to measure any variation in response. One of the most important advantages of this method is the limited number of experiments necessary to identify the best solution.

Reaction temperature (K), reaction pressure (bar), $\mathrm{H}_{2} / \mathrm{CO}_{2}$ ratio, and the recycle of produced stream were considered as factors in this research. The methanol production $(\mathrm{kg} / \mathrm{h})$ and the reactor volume $\left(\mathrm{m}^{3}\right)$ were considered as responses, for which a mathematical model was developed.

\subsection{Response Surface Methodology}

Response surface methodology (RSM) combined with central composite design is an efficient technique for experimentally exploring relationships between investigated factors and system response [53]. The aim of RSM is to find the optimal operating conditions of the process or to determine a region which satisfies the operating specifications, maintaining a reduced number of experiments [54]. For these reasons, RMS is used in process design and optimization. The design procedure for RSM is as follows [53]: to design a series of experiments for sufficient and reliable measurement of the desirable response; to develop a mathematical model with a second-order response surface and maximum fitting; to determine the most desirable set of experimental parameters that produce a maximum or minimum value of the response; to express the direct and interactive effects of process parameters as two- and three-dimensional plots.

CCD requires three types of tests: $2 k$ factorial tests, $2 k$ axial tests, and $n_{\mathrm{c}}$ center point tests, where $k$ is the number of factors studied in the experiment [52]. In order to be ratable, the design is represented by five levels $-\alpha,-1,0,1, \alpha$, with $\alpha$ equal to $\left(2^{\mathrm{k}}\right)^{0.25}$ [55]. This property ensures a constant variance at points that are equidistant from the central point, and therefore provides the equal precision of response estimation in any direction of the design.

The experimental data were used to develop a second-order polynomial model as in the following correlation (see Equation (12)) [56]:

$$
Y=\beta_{o}+\sum_{i=1}^{k} \beta_{i} \times A_{i}+\sum_{i=1}^{k} \sum_{j=1}^{k} \beta_{i j} \times A_{i} \times A_{j}+\sum_{i=1}^{k} \beta_{i i} \times A_{i}^{2}+\varepsilon
$$

where $\beta_{o}$ is intercept, $\beta_{i}, \beta_{i j}, \beta_{i i}$ are first-order, interactive, and second-order effects, respectively, $i$ and $j$ represent the number of $k$ factors, while $\varepsilon$ is residual error. This method is then able to evaluate interaction effects, pure quadratic effects, or third- and fourth-order effects and so on; it is the most efficient evaluation method, and it improves the quality of data. 
To determine the significance of each term in the equation and to estimate the goodness or fitting quality, the polynomial equation was validated by analysis of variance (ANOVA). A response surface plot was constructed by using the fitted model.

A CCD design with four factors at five levels with 26 simulations test was developed in this research in order to find a response surface for the methanol production. In particular, 16 cubical, 2 center, and 8 axial points were tested in the CCD design. Values at the center point are used to detect curvature in the response, and they contribute to estimation of coefficients for quadratic terms. Axial points (located at distance $\alpha$ from central point) are also used to estimate the coefficients of quadratic terms, while factorial points (located at the corners of cube with a side length equal to 2) are used mainly in order to estimate the coefficients of linear terms and two-way interactions.

The analyzed factors were the same as those of the ANOVA analysis: reaction temperature $(\mathrm{K})$, reaction pressure (bar), $\mathrm{H}_{2} / \mathrm{CO}_{2}$ ratio, the recycle of produced stream. JMP 13 software was used for this analysis.

\section{Results and Discussion}

\subsection{Results of ANOVA Analysis}

ANOVA has not been used yet to study methanol reactors in literature. Table 3 shows factors (reaction temperature, reaction pressure, $\mathrm{H}_{2} / \mathrm{CO}_{2}$ ratio, the recycle of produced stream) and the values of their levels selected for the system, producing methanol by the hydrogenation of carbon dioxide. Levels taken in consideration for each factor identify different factorial plans.

Table 3. Factors and values of levels chosen in the factorial design of ANOVA analysis.

\begin{tabular}{cccc}
\hline \multirow{2}{*}{ Code } & Factors & \multicolumn{2}{c}{ Levels } \\
\cline { 3 - 4 } & & $\mathbf{( - )}$ & $\mathbf{( + )}$ \\
\hline$A$ & Reaction temperature (K) & 473 & 573 \\
$B$ & Reaction pressure (bar) & 50 & 100 \\
$C$ & $\mathrm{H}_{2} / \mathrm{CO}_{2}$ ratio & 1 & 3 \\
$D$ & The recycle of produced stream & no & yes \\
\hline
\end{tabular}

The studied responses were the methanol production and the reactor volume. The first response provides information about the productivity of the process, while the second response provides information about reactor and catalyst costs. A higher volume determines a higher catalyst mass and thus higher catalyst costs, in addition to higher reactor costs. It is preferable to have a higher productivity with lower costs. Figure 2 shows the results of ANOVA analysis: only significant factors and the values of their effects for the studied responses are reported. An effect can be considered as the variation of the analyzed response after the variation of the considered factor. In a positive effect, the increase of a factor produces an increase of response; in a negative effect, the increase of a factor produces a decrease of response. Meanwhile, in an interaction, the variation of two or three factors produces the variation (with a positive or negative effect) of response.

Table 4 shows the statistical results of ANOVA analysis for methanol production obtained in all tests.

Results show that reaction temperature has a negative effect on the methanol production: the increase of temperature leads to a decrease of the production. Since hydrogenation reactions of $\mathrm{CO}$ and $\mathrm{CO}_{2}$ are exothermic, their rates increase with temperature, but only up to a certain temperature. At higher temperatures, rates begin to decrease because the thermodynamic equilibrium constant decreases as temperature increases [57]. Xin et al. [58] found that methanol yield and carbon dioxide conversion decrease with temperature. Yang et al. [59] proposed that low-temperature methanol production enables high conversions of up to $50-80 \%$ and the reduction of production costs without any thermodynamic equilibrium. Extreme temperature limits the efficiency of methanol production 
due to thermodynamic limitations. Shen et al. [60] found that both temperature and pressure have a considerable effect on equilibrium yields. The equilibrium conversion of $\mathrm{CO}_{2}$ to methanol increases distinctively with increasing pressure and decreases strongly as temperature increases.

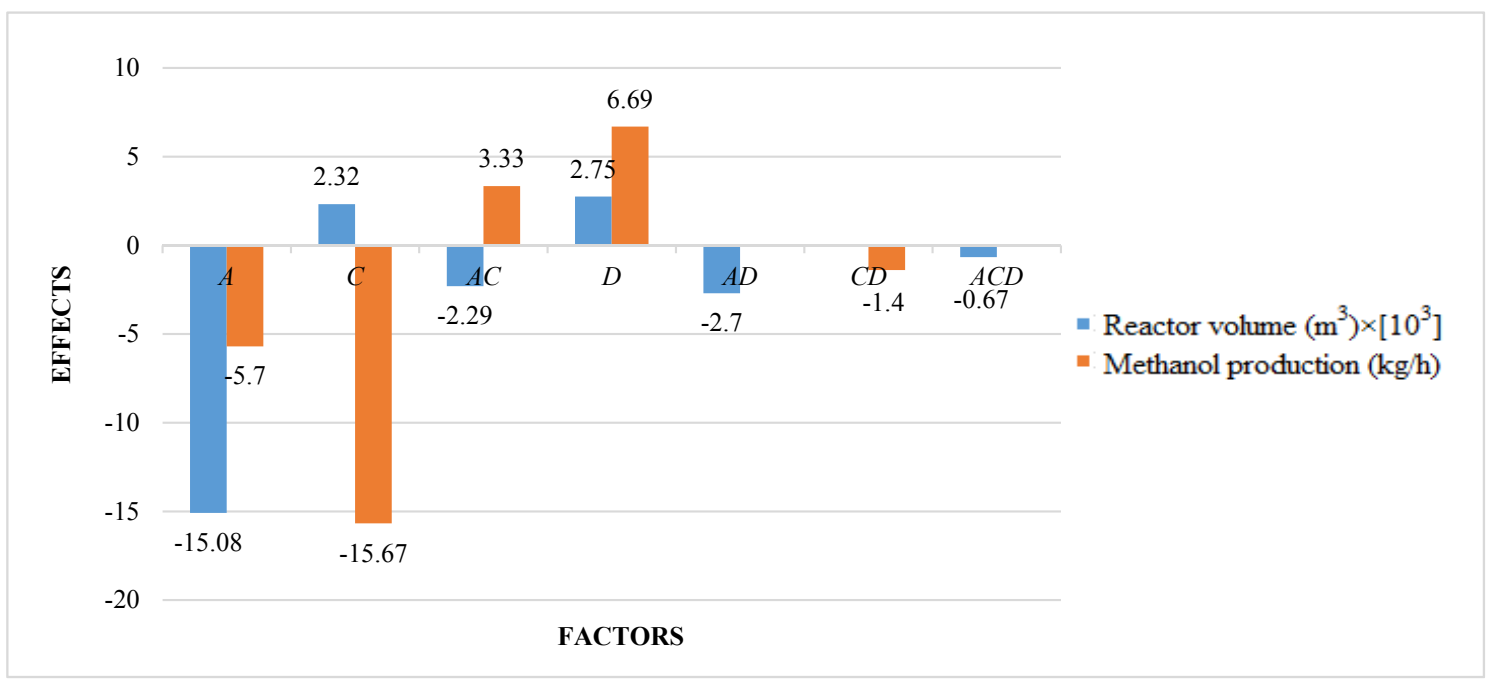

Figure 2. Results of ANOVA analysis (only significant factors and values of their effects) considering the reactor volume and the methanol production as responses $(A=$ reaction temperature in $\mathrm{K}, B=$ reaction pressure in bars, $\mathrm{C}=\mathrm{H}_{2} / \mathrm{CO}_{2}$ ratio, $D=$ the recycle of produced stream).

Table 4. Results of ANOVA analysis considering the response of methanol production.

\begin{tabular}{ccccccc}
\hline Trial & $\begin{array}{c}\text { Methanol } \\
\text { Production (kg/h) }\end{array}$ & Effect (kg/h) & Sum of Square & F-Value & $\boldsymbol{p}$-Value & Significance \\
\hline$(1)$ & 34,108 & & & & & \\
a & 26,181 & -5700 & $1.30 \times 10^{8}$ & 128.98 & 0.00146 & $100 \%$ \\
b & 34,113 & 332.5 & $4.42 \times 10^{5}$ & 0.44 & 0.54388 & $46 \%$ \\
ab & 25,915 & 346 & $4.79 \times 10^{5}$ & 0.48 & 0.52849 & $47 \%$ \\
c & 17,289 & -15678 & $9.83 \times 10^{8}$ & 975.79 & 0.00001 & $100 \%$ \\
ac & 14,371 & 3337.5 & $4.46 \times 10^{7}$ & 44.22 & 0.00266 & $100 \%$ \\
bc & 17,285 & 481 & $9.25 \times 10^{5}$ & 0.92 & 0.39215 & $61 \%$ \\
abc & 14,250 & 494 & $9.76 \times 10^{5}$ & 0.97 & 0.38071 & $62 \%$ \\
d & 43,178 & 6692 & $1.79 \times 10^{8}$ & 177.78 & 0.00018 & $100 \%$ \\
ad & 33,326 & -180.5 & $1.30 \times 10^{5}$ & 0.13 & 0.73730 & $26 \%$ \\
bd & 43,172 & 429 & $7.36 \times 10^{5}$ & 0.73 & 0.44086 & $56 \%$ \\
abd & 32,999 & 443 & $7.85 \times 10^{5}$ & 0.78 & 0.42728 & $57 \%$ \\
cd & 21,992 & -1397.5 & $7.81 \times 10^{6}$ & 7.75 & 0.04959 & $95 \%$ \\
acd & 18,505 & 794.5 & $2.52 \times 10^{6}$ & 2.51 & 0.18859 & $81 \%$ \\
bcd & 21,943 & 447 & $7.99 \times 10^{5}$ & 0.79 & 0.42346 & $58 \%$ \\
abcd & 21,933 & 455.5 & $8.30 \times 10^{5}$ & 0.82 & 0.41544 & $58 \%$ \\
\hline
\end{tabular}

$\mathrm{H}_{2} / \mathrm{CO}_{2}$ ratio has the highest effect on the methanol production: it has a negative effect, but in interaction with factor $A$, in second-order interaction $A C$, the effect is positive. Then, a simultaneous variation of factors $A$ and $C$ determines the increase of methanol production.

Generally, the methanol production increases with the increasing of carbon dioxide mole fraction in the feed, and then with the decreasing of $\mathrm{H}_{2} / \mathrm{CO}_{2}$ ratio. Al-Dwani [61] showed that methanol production rate increases with the increasing of mole percent in the feed up to the optimum value of carbon dioxide mole percent in the feed of 4.7 , at which point methanol production rate reaches a maximum value and after which methanol production rate starts to decrease with the increasing of carbon dioxide mole percent in the feed. This behavior can be attributed to fact that the hydrogenation 
of one mole of $\mathrm{CO}$ to methanol needs two moles of $\mathrm{H}_{2}$, compared to $\mathrm{CO}_{2}$ which needs three moles of $\mathrm{H}_{2}$ to form methanol. Therefore, under lean hydrogen conditions, hydrogenation of $\mathrm{CO}$ activity is increased. However, as $\mathrm{CO}_{2}$ content in the feed increases, overall rate decreases since the hydrogenation of $\mathrm{CO}$ is inhibited by increased amounts of $\mathrm{CO}_{2}$ in the feed. Then both $\mathrm{CO}$ and $\mathrm{CO}_{2}$ conversions in the methanol reactor decrease with the increase of $\mathrm{CO}_{2}$ fraction. Generally, the optimal $\mathrm{H}_{2} / \mathrm{CO}_{2}$ ratio is about 3 [62].

The same consideration is for the recycle of produced stream, factor $D$ : it has a positive effect on the methanol production (by increasing recycling, the methanol production increases), but the effect is negative in interaction with factor $C$. In fact, methanol reaction is limited by chemical equilibrium, and the recycling flow can prevent related problems-particularly at high temperature, increasing the methanol production [63]. Obviously, recycling the stream increases the amount of total feed, and consequently $\mathrm{CO}$ and $\mathrm{CO}_{2}$ conversion is decreased due to decreased residence time. However, since productivity is defined as the product of feed flow rate and conversion, net productivity is improved. A mathematical model can be obtained by ANOVA analysis for the methanol production, as in the following relation, as a function of significant factors and interactions (see Equation (13)):

$$
Y=26285-2850 \times X_{1}-7839 \times X_{3}+1668 \times X_{1} \times X_{3}+3346 \times X_{4}-698 \times X_{3} \times X_{4}\left(R^{2}=0.99\right)
$$

where $Y$ is the methanol production in $\mathrm{kg} / \mathrm{h}, \mathrm{X}_{1}$ is reaction temperature in Kelvin, $\mathrm{X}_{3}$ is $\mathrm{H}_{2} / \mathrm{CO}_{2}$ ratio, and $X_{4}$ is the recycle of produced stream. A value of $R^{2}$ equal to 0.99 is close to unity, which indicates that the predictive model is precise enough to explain a relation between process parameters and the methanol production.

Analyzing the obtained results for the reactor volume, reaction temperature has a negative effect: with a higher temperature, there is a lower methanol production and a lower reactor volume. In fact, with a lower methanol production and thus with a lower outlet flow rate, the reactor volume is lower, being calculated with an integration of molar flow rate at the inlet and at the outlet of the reactor [64]. $\mathrm{H}_{2} / \mathrm{CO}_{2}$ ratio has a positive effect on the reactor volume. In fact, with a higher ratio, a higher hydrogen is available for reactions thatevolving require a higher catalyst mass, which increases the reactor volume. However, interaction $A C$ has a negative effect on the reactor volume: the positive effect of factor $C$ is avoided in interaction with factor $A$. Recycling has a positive effect on the reactor volume, because a higher flow rate is present in the feed and then at the outlet of the reactor. Instead, the second-order interaction $A D$ has a negative effect. The third order interaction $A C D$ is also significant with a negative effect, but its effect is lower compared to other significant effects for the analyzed response. For the reactor volume, a mathematical model can be obtained with significant factors, as in the following relation (see Equation (14)):

$$
y=80.9-75.4 \times X_{1}+11.6 \times X_{3}-11.5 \times X_{1} \times X_{3}+13.7 \times X_{4}-13.5 \times X_{1} \times X_{4}-3.3 \times X_{1} \times X_{4} \times X_{3}\left(R^{2}=0.99\right)
$$

where $y$ is the reactor volume in $\mathrm{m}^{3}, \mathrm{X}_{1}$ is reaction temperature in Kelvin, $\mathrm{X}_{3}$ is $\mathrm{H}_{2} / \mathrm{CO}_{2}$ ratio, and $X_{4}$ is the recycle of produced stream. A value of $R^{2}$ equal to 0.99 ensures a good agreement between simulation and modeling data. Table 5 shows the results obtained by ANOVA analysis for the reactor volume.

Comparing the results of two factorial designs, it is evident that only interaction AC allows the methanol production to be increased and the reactor volume and thus the catalyst mass to be decreased. A higher production is ensured with lower costs. In fact, upon increasing reaction temperature, both methanol production and reactor volume decrease. Increasing $\mathrm{H}_{2} / \mathrm{CO}_{2}$ ratio, the methanol production decreases but the reactor volume increases. Increasing recycling, the two analyzed responses increase. These solutions, then, are not suitable to improve the production of the system with lower costs. Only interaction $A C$ ensures that the aim of this study is satisfied. Varying reaction temperature and $\mathrm{H}_{2} / \mathrm{CO}_{2}$ ratio, the methanol production increases, while the reactor volume decreases. This consideration can be observed in Figure 3a, where a surface plot of the methanol 
production in $\mathrm{kg} / \mathrm{h}$ is obtained as a function of temperature and $\mathrm{H}_{2} / \mathrm{CO}_{2}$ ratio with a recycling equal to $30 \%$. The plot is obtained considering the mathematical model of Equation (14). According to previous results and considering one factor at a time, the plot decreases when increasing reaction temperature, while it increases with increasing $\mathrm{H}_{2} / \mathrm{CO}_{2}$ ratio. The presence of an interaction between factors $A$ and $C$ is evident, where interaction $A C$ has a positive effect. In fact, the plot does not have a linear pattern, underling the second-order nature of the interaction. It is possible to notice that only $\mathrm{H}_{2} / \mathrm{CO}_{2}$ ratios that are higher than 1.6 can be accepted in the process, because for lower ratios a negative methanol production is obtained by the mathematical model. In this way, it is possible to find the possible operating conditions of the reactor. Optimal operating conditions can be obtained at higher temperature and $\mathrm{H}_{2} / \mathrm{CO}_{2}$ ratio. Higher values of methanol production that can be obtained are in the range of $1,000,000-1,500,000 \mathrm{~kg} / \mathrm{h}$.

Table 5. Results of ANOVA analysis considering the response of reactor volume.

\begin{tabular}{ccccccc}
\hline Trial & Reactor Volume $\left.\mathbf{( m}^{\mathbf{3}}\right)$ & Effect $\left.\mathbf{( m}^{\mathbf{3}}\right)$ & Sum of Square & $\boldsymbol{F}$-Value & $\boldsymbol{p}$-Value & Significance \\
\hline$(1)$ & 115 & & & & & \\
$\mathrm{a}$ & 4.63 & -150.83 & $9.10 \times 10^{4}$ & 4058.65 & 0.0000004 & $100 \%$ \\
$\mathrm{~b}$ & 109 & -4.02 & $6.45 \times 10^{1}$ & 2.88 & 0.1652 & $83 \%$ \\
$\mathrm{ab}$ & 4.37 & 2.02 & $1.63 \times 10^{1}$ & 0.73 & 0.4416 & $56 \%$ \\
$\mathrm{c}$ & 150.9 & 23.27 & $2.17 \times 10^{3}$ & 96.61 & 0.0006 & $100 \%$ \\
$\mathrm{ac}$ & 6.2 & -22.99 & $2.11 \times 10^{3}$ & 94.30 & 0.0006 & $100 \%$ \\
$\mathrm{bc}$ & 141.4 & -0.16 & $1.06 \times 10^{-1}$ & 0.005 & 0.9486 & $5 \%$ \\
$\mathrm{abc}$ & 5.8 & -1.53 & 9.33 & 0.42 & 0.5539 & $45 \%$ \\
$\mathrm{~d}$ & 158.8 & 27.51 & $3.03 \times 10^{3}$ & 135.00 & 0.0003 & $100 \%$ \\
$\mathrm{ad}$ & 6.4 & -27.00 & $2.92 \times 10^{3}$ & 130.09 & 0.0003 & $100 \%$ \\
$\mathrm{bd}$ & 150 & 0.02 & $2.50 \times 10^{-3}$ & 0.0001 & 0.9921 & $1 \%$ \\
$\mathrm{abd}$ & 6.05 & -1.69 & $1.14 \times 10^{1}$ & 0.51 & 0.5148 & $49 \%$ \\
$\mathrm{~cd}$ & 212.69 & 5.45 & $1.19 \times 10^{2}$ & 5.29 & 0.0829 & $92 \%$ \\
$\mathrm{acd}$ & 8.77 & -6.66 & $1.78 \times 10^{2}$ & 7.93 & 0.0481 & $95 \%$ \\
$\mathrm{bcd}$ & 212.85 & 0.75 & 2.24 & 0.10 & 0.7680 & $23 \%$ \\
$\mathrm{abcd}$ & 1.8 & -2.37 & $2.24 \times 10^{1}$ & 1.00 & 0.3739 & $63 \%$ \\
\hline
\end{tabular}

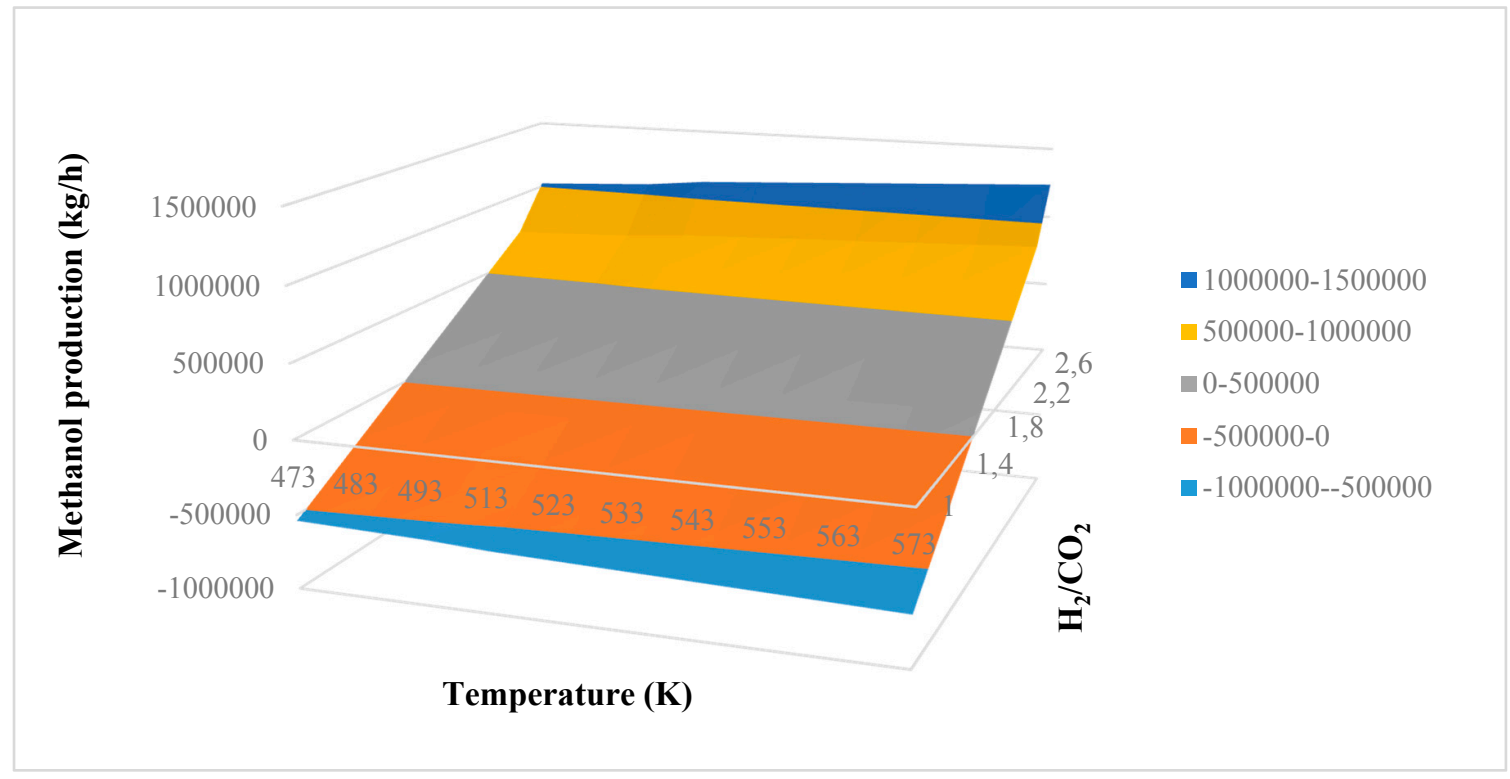

Figure 3. Surface plot of methanol production versus reaction temperature and $\mathrm{H}_{2} / \mathrm{CO}_{2}$ ratio (color code $=$ methanol production in $\mathrm{kg} / \mathrm{h}$ ). 


\subsection{Analysis of Factors and Interactions in ANOVA Analysis}

Significant factors and interactions were found with ANOVA analysis for both methanol production and reactor volume. An accurate analysis could be also developed to support the significance of interaction factors. Figure $4 \mathrm{a}, \mathrm{b}$ shows interactions $A C$ and $C D$, respectively, for the methanol production. If reaction temperature is at a higher level, $\mathrm{H}_{2} / \mathrm{CO}_{2}$ ratio at lower level produces a higher methanol flow rate at the outlet of the reactor; if reaction temperature is at a lower level, $\mathrm{H}_{2} / \mathrm{CO}_{2}$ ratio at a higher level produces a lower methanol flow rate at the outlet of the reactor. Interaction $A C$ is positive: the negative effect of temperature decreases at the lowest level of $\mathrm{H}_{2} / \mathrm{CO}_{2}$ ratio. The same consideration can be carried out for the $C D$ interaction: at higher level of factor $D$, the methanol production decreases when increasing factor $C$, while at lower level of factor $D$ a higher productivity is ensured with factor $C$ at a lower level. Interaction $C D$ is negative: this means that the positive effect of recycling decreases at the highest level of $\mathrm{H}_{2} / \mathrm{CO}_{2}$ ratio.
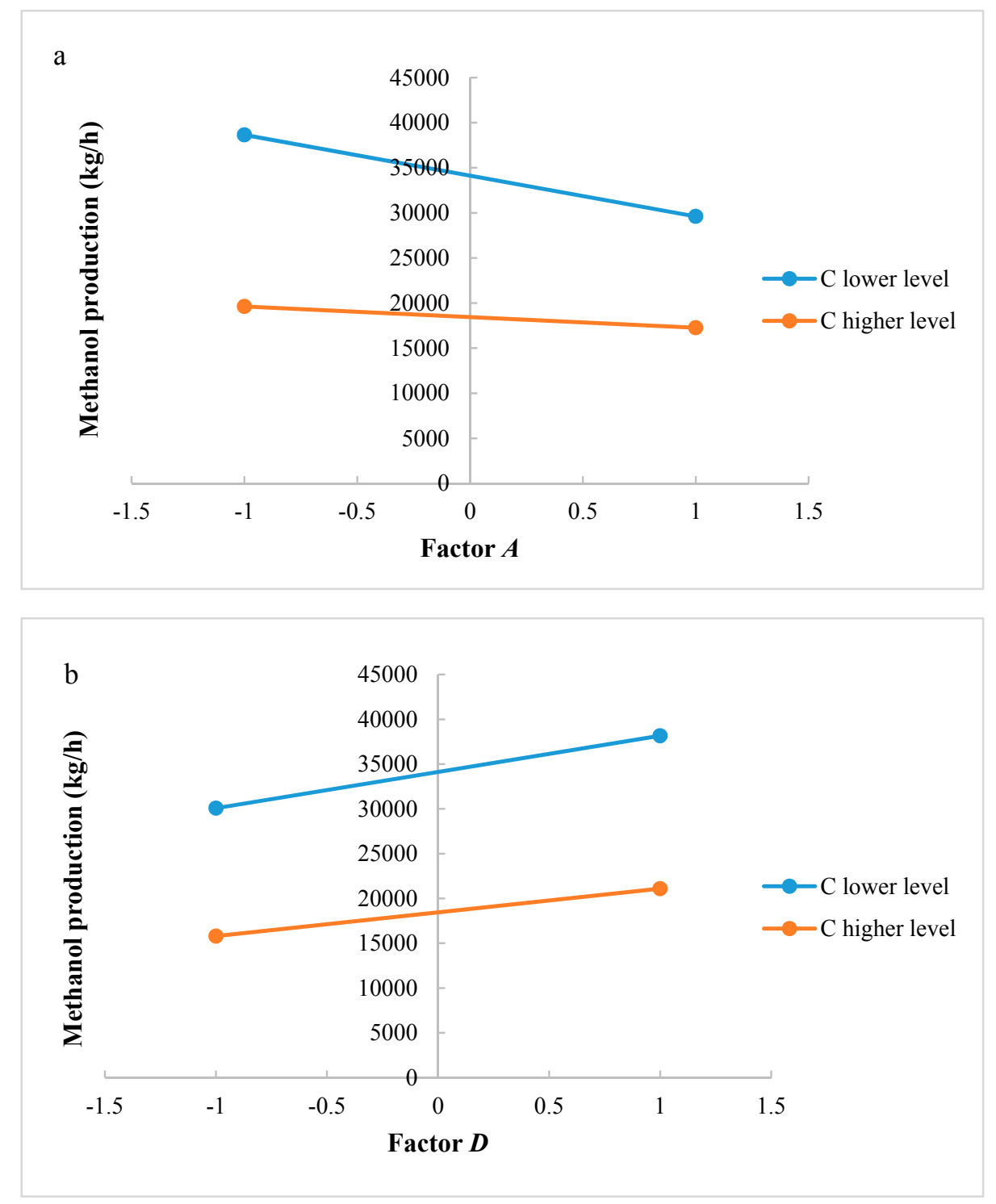

Figure 4. (a) Test of two levels for the analysis of interaction $A C$ in the methanol production; (b) Test of two levels for the analysis of interaction $C D$ in the methanol production. $(A=$ reaction temperature in $\mathrm{K}, \mathrm{C}=\mathrm{H}_{2} / \mathrm{CO}_{2}$ ratio, $\mathrm{D}=$ the recycle of produced stream). 
Figure $5 \mathrm{a}-\mathrm{c}$ shows residues (difference between an observation and its estimated value from mathematical model) versus the levels of factors $A, C$, and $D$, respectively, in order to study the variability of the process. A lower variability in methanol production is present with factors $A$ and $D$ at lower levels and factor $C$ at a higher level. These operative conditions are then preferable, because they ensure a higher process stability.

The same considerations regarding the study of significant interactions could be carried out for the reactor volume. Figure $6 \mathrm{a}, \mathrm{b}$ shows interactions $A C$ and $A D$, respectively. In interaction $A C$, for factor $A$ at higher level, an increase of $\mathrm{H}_{2} / \mathrm{CO}_{2}$ ratio does not improve the reactor volume. However, when factor $A$ is at a lower level, $\mathrm{H}_{2} / \mathrm{CO}_{2}$ ratio increases the reactor volume. Interaction $A C$ has a negative effect on the reactor volume: the positive effect of factor $A$ decreases at the lowest level of factor $C$. In interaction $A D$, when factor $A$ is at the higher level, an increase of factor $D$ does not increase the reactor volume; in contrast, at lower level of factor $A$, a higher level of factor $D$ determines a higher reactor volume. Interaction $A D$ has a negative effect on the reactor volume: the positive effect of factor $A$ decreases at the lowest level of factor $D$.

A common interaction for the two analyzed responses is $A C$. Results show that in order to have an increase of the methanol production without increasing the reactor volume, the better solution is to work with factor $A$ at a higher level and $\mathrm{H}_{2} / \mathrm{CO}_{2}$ ratio at a lower level. In fact, even if the increase of methanol production is not the maximum available, the reactor volume is lower. At a higher level of factor $A$, a variation of factor $C$ does not significantly affect the reactor volume: it is possible to choose a level that maximizes the production and minimizes the reactor volume. This allows lower catalyst and reactor costs to be obtained.

Figure 7a-c shows residues versus the level of factors $A, C$, and $D$, respectively. Results show that a lower variability of the reactor volume is present with factor $A$ at a higher level. In other cases, significant differences are not present. It is evident that a key interaction for the process is interaction $A C$ : a higher productivity is ensured with a lower catalyst mass and reactor volume. In particular, it is preferable to work with factor $A$ at a higher level and factor $C$ at a lower level.

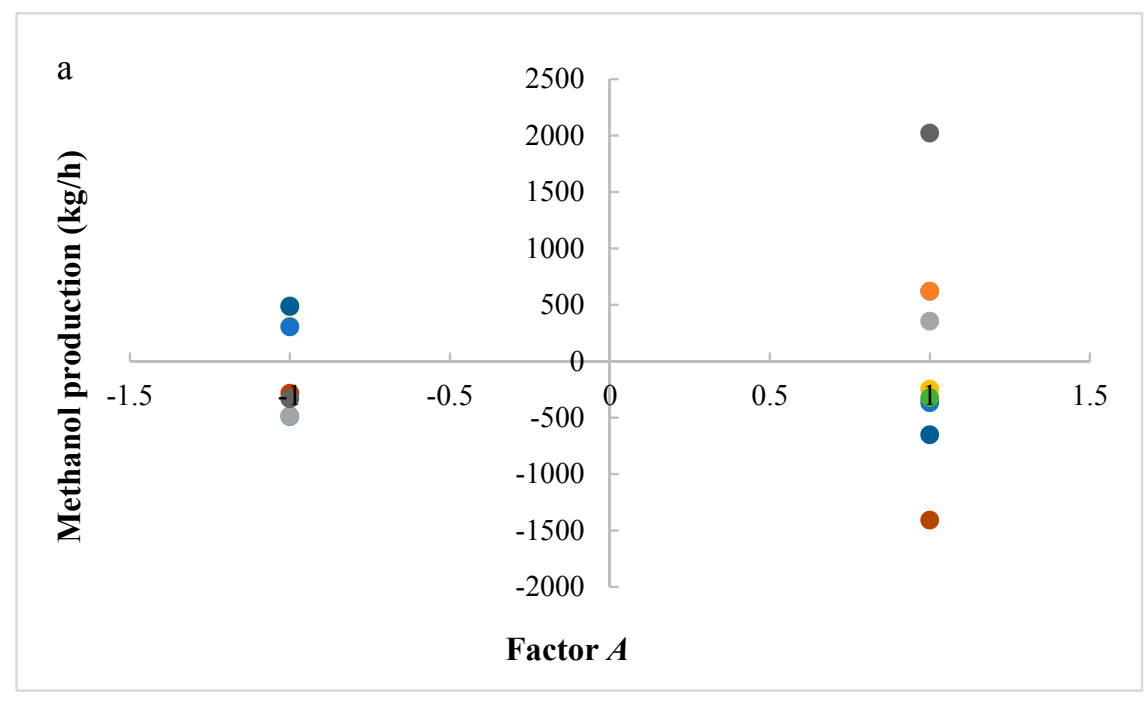

Figure 5. Cont. 


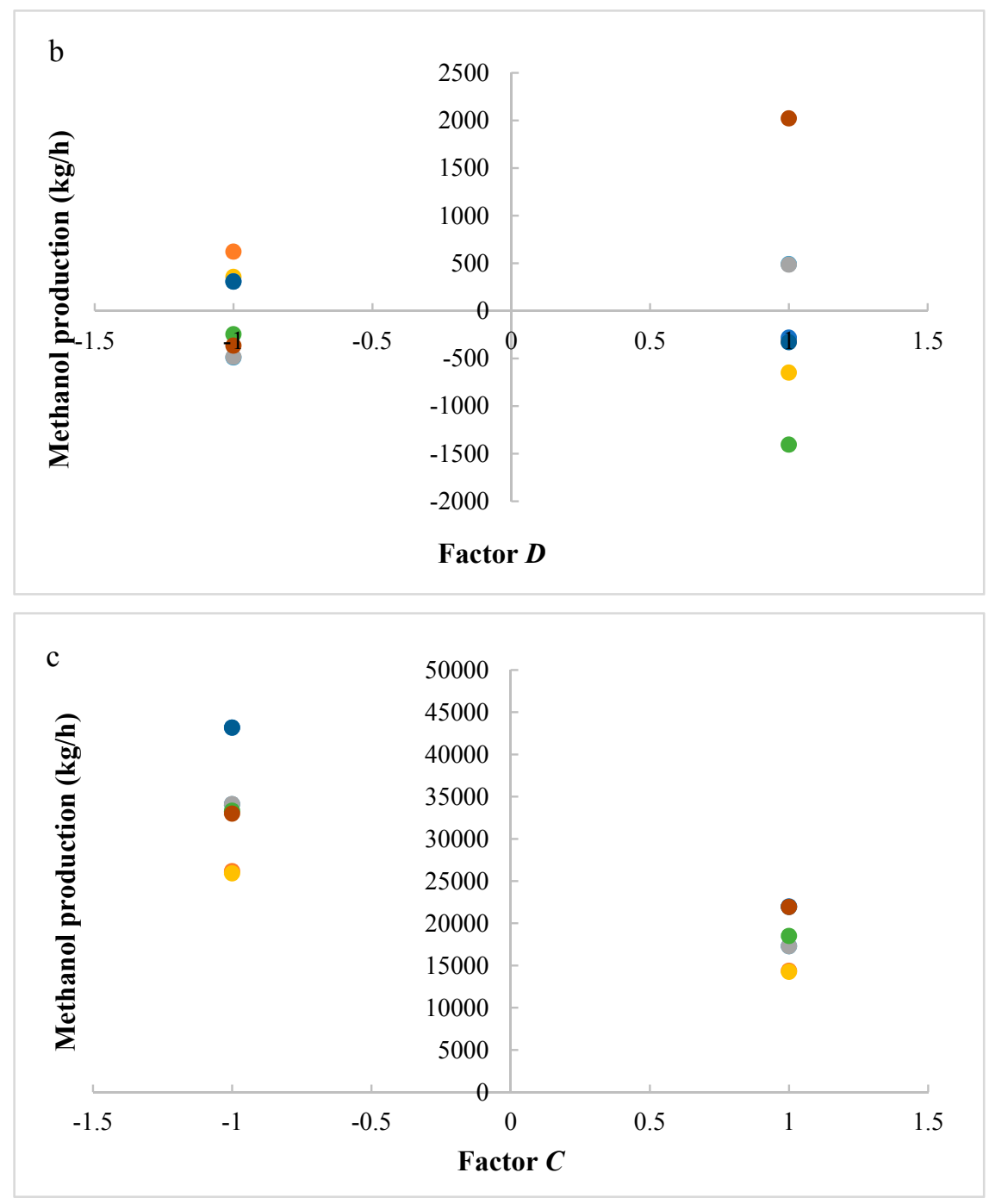

Figure 5. (a) Residues of methanol production versus levels for factor $A$; (b) Residues of methanol production versus levels for factor $D$; (c) Residues of methanol production versus levels for factor $C$. ( $A$ = reaction temperature in $\mathrm{K}, \mathrm{C}=\mathrm{H}_{2} / \mathrm{CO}_{2}$ ratio, $D=$ the recycle of produced stream).

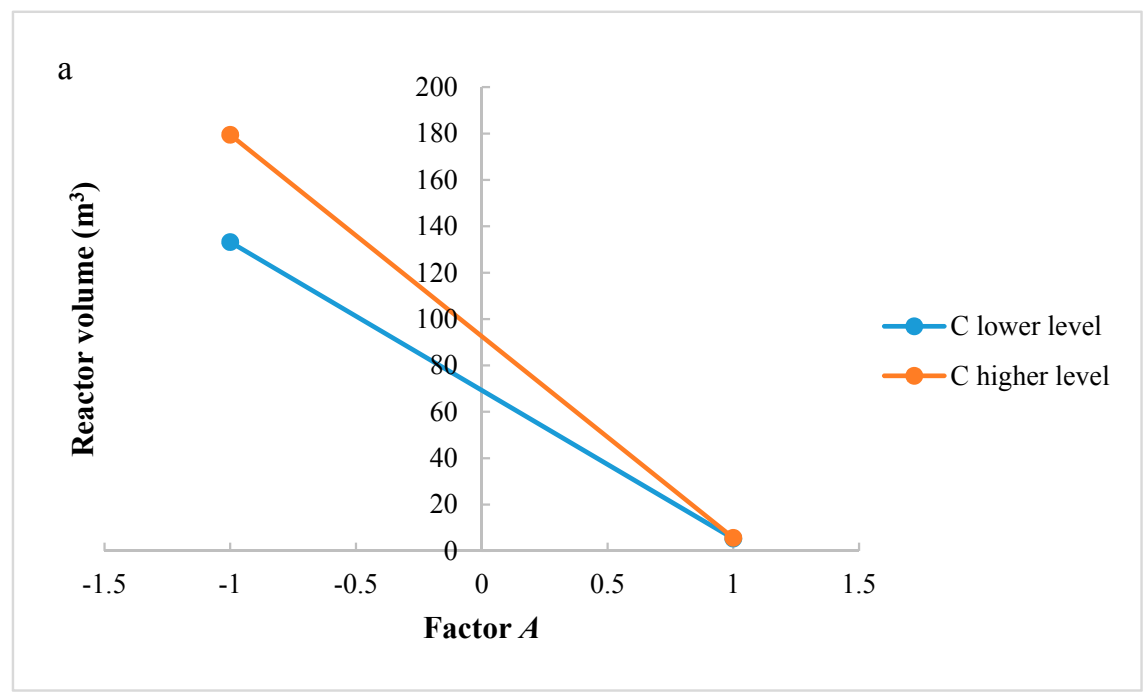

Figure 6. Cont. 


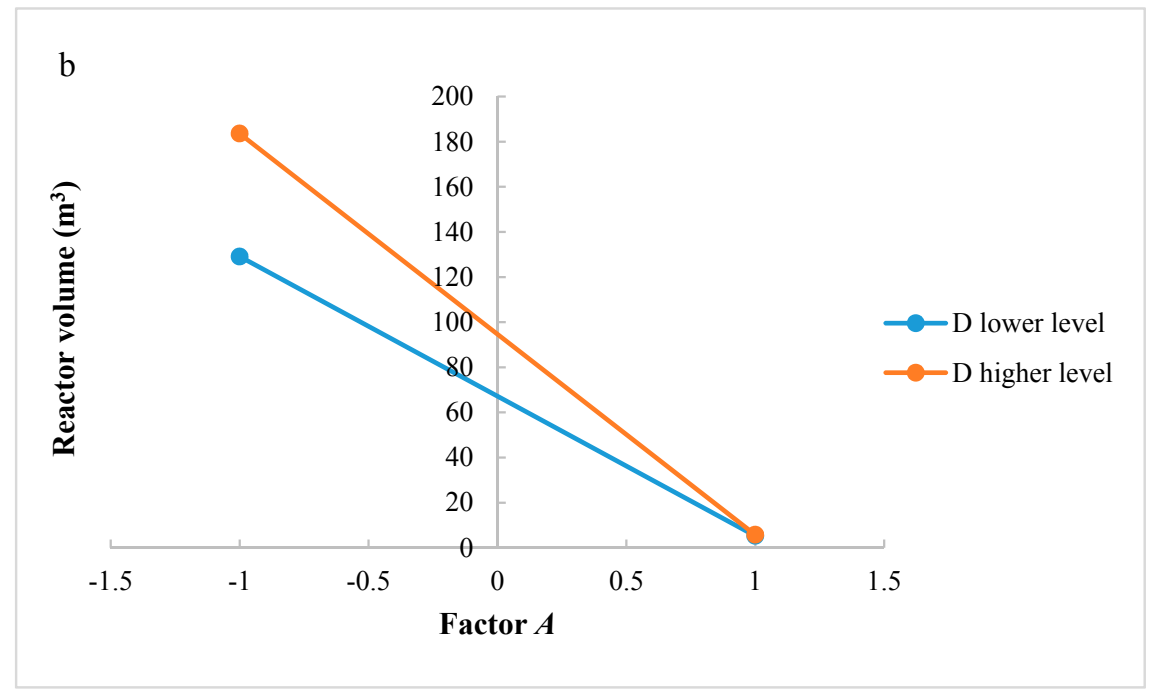

Figure 6. (a) Test of two levels for the analysis of interaction $A C$ in the reactor volume; (b) Test of two levels for the analysis of interaction $C D$ in the reactor volume. ( $A$ = reaction temperature in $\mathrm{K}$, $\mathrm{C}=\mathrm{H}_{2} / \mathrm{CO}_{2}$ ratio, $\mathrm{D}=$ the recycle of produced stream).

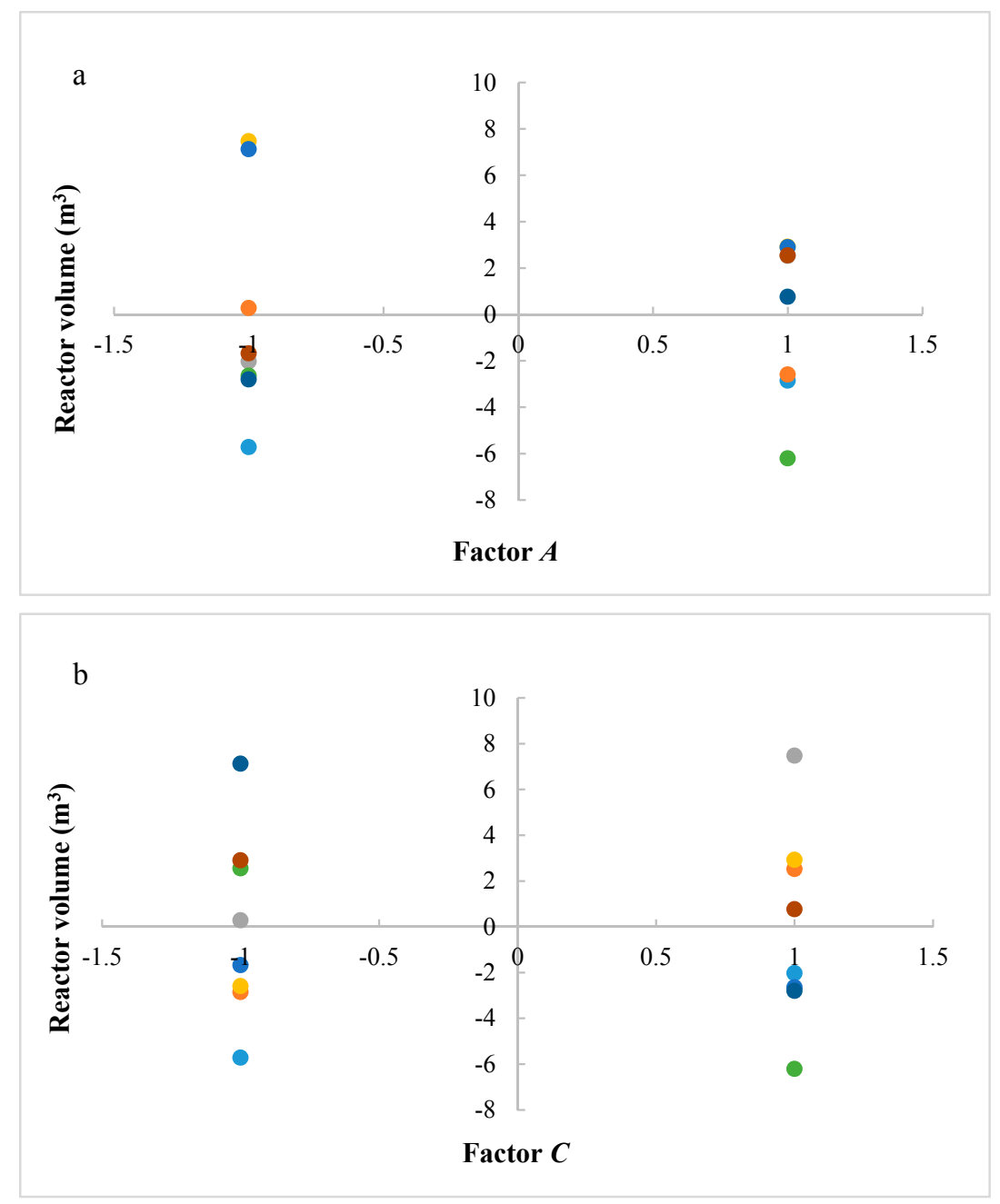

Figure 7. Cont. 


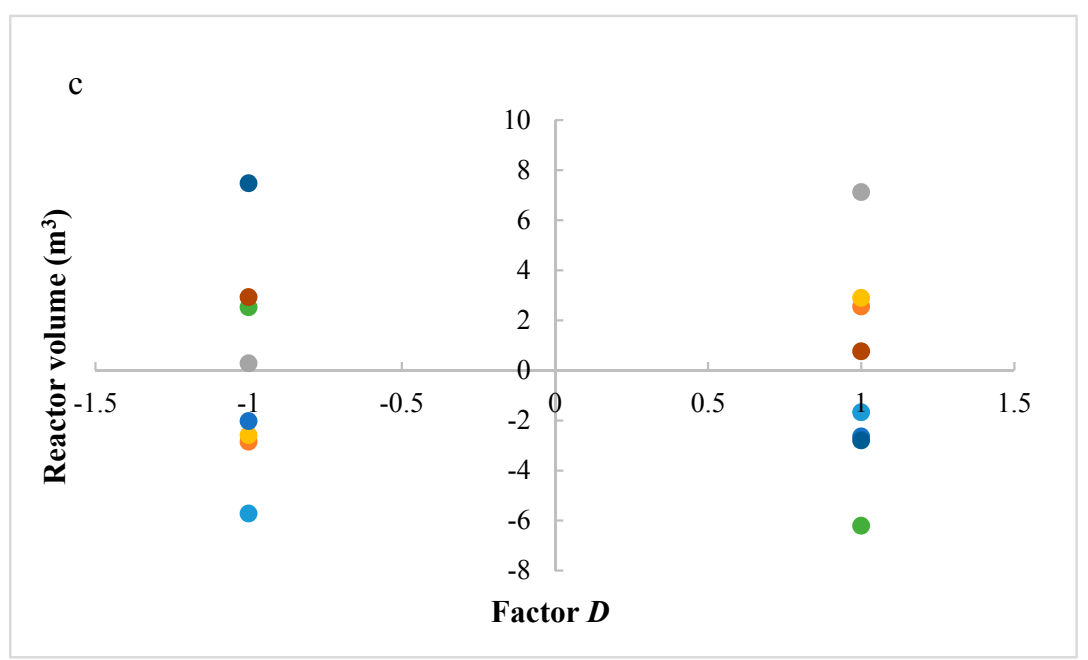

Figure 7. (a) Residues of reactor volume versus levels for factor $A$; (b) Residues of reactor volume versus levels for factor $C$; (c) Residues of reactor volume versus levels for factor $D$. ( $A$ = reaction temperature in $\mathrm{K}, \mathrm{C}=\mathrm{H}_{2} / \mathrm{CO}_{2}$ ratio, $\mathrm{D}=$ the recycle of produced stream).

\subsection{Results of Response Surface Methodology}

RSM is an effective statistical tool that helps in analysis considering interactions between different parameters, and reduces time, cost, and process variability percentage, thus providing an optimal global solution. Table 6 shows the chosen factors and their levels set in a composite central design, used to find the response surface plot for the methanol production. Factors are the same used in previous ANOVA analysis: reaction temperature in Kelvin, reaction pressure in bar, $\mathrm{H}_{2} / \mathrm{CO}_{2}$ ratio in the feed of reactor, the recycle of produced stream. The methanol production is the analyzed response. The aim of the response surface methodology in this research was to find the optimal operating conditions of the process, in a better way compared to previous ANOVA analysis. After a primary general study, a better comprehension of the process was then obtained.

Table 6. Factors and values of the levels chosen in central composite design.

\begin{tabular}{ccccccc}
\hline \multirow{2}{*}{ Code } & Factors & \multicolumn{5}{c}{ Levels } \\
\cline { 3 - 6 } & & $\mathbf{- 2}$ & $\mathbf{- 1}$ & $\mathbf{0}$ & $\mathbf{1}$ & $\mathbf{2}$ \\
\hline$A$ & Reaction temperature (K) & 423 & 473 & 523 & 573 & 623 \\
$B$ & Reaction pressure (bar) & 25 & 50 & 75 & 100 & 125 \\
$C$ & $\mathrm{H}_{2} / \mathrm{CO}_{2}$ ratio & 0.8 & 1 & 1.5 & 3 & 3.2 \\
$D$ & The recycle of produced stream & purge & no & $5 \%$ & yes & $20 \%$ \\
\hline
\end{tabular}

Table 7 shows the result of ANOVA analysis for CCD study, carried out with JMP software. Parameters showing $p$ values lesser than 0.05 were considered to be significant and were involved in the development of the regression equation. A $p$-value less than 0.05 indicates a good model term, whereas a value greater than 0.05 indicates a poor model term, which can be ignored.

With significant factors and interactions, a mathematical model for the methanol production was found according to following polynomial quadratic equation (see Equation (15)):

$$
M_{\text {eth }}=27412-2717.75 \times X_{1}-7715.95 \times X_{3}+3089.59 \times X_{4}+1668.75 \times X_{1} \times X_{3}-1078.74 \times X_{1}^{2}\left(R^{2}=0.99\right)
$$

where $M_{\text {eth }}$ is the methanol flow rate in $\mathrm{kg} / \mathrm{h}, \mathrm{X}_{1}$ is reaction temperature in Kelvin, $\mathrm{X}_{3}$ is $\mathrm{H}_{2} / \mathrm{CO}_{2}$ ratio, $X_{4}$ is the recycle of produced stream. A regression coefficient, $R^{2}$, equal to 0.99 indicates a high degree of correlation between simulation and predicted data. This ensures the use of the model as a promising representative of the simulator for further analysis. 
Table 7. Results of statistical analysis of evaluated parameters in central composite design (CCD) $\left(X_{1}=\right.$ reaction temperature in $\mathrm{K}, X_{2}=$ reaction pressure in bar, $X_{3}=\mathrm{H}_{2} / \mathrm{CO}_{2}$ ratio, $X_{4}=$ the recycle of produced stream).

\begin{tabular}{ccccccc}
\hline Parameter & Estimate & Standard Error & Sum of Square & F-Ratio & $p$-Value & Status \\
\hline$X_{1}$ & -2717.75 & 725.66 & $1.51 \times 10^{8}$ & 83.8758 & 0 & Significant \\
$X_{2}$ & 130.56 & 296.74 & $3.48 \times 10^{5}$ & 0.1936 & 0.6684 & Not Significant \\
$X_{3}$ & -7715.95 & 296.74 & $1.21 \times 10^{9}$ & 676.12 & 0 & Significant \\
$X_{4}$ & 3089.59 & 296.74 & $1.95 \times 10^{8}$ & 108.4 & 0 & Significant \\
$X_{1} X_{2}$ & 173 & 335.03 & $4.79 \times 10^{5}$ & 0.2666 & 0.6158 & Not Significant \\
$X_{1} X_{3}$ & 1668.75 & 335.03 & $4.46 \times 10^{7}$ & 24.8 & 0.00041 & Significant \\
$X_{1} X_{4}$ & -90.25 & 335.03 & $1.30 \times 10^{5}$ & 0.0726 & 0.7926 & Not Significant \\
$X_{2} X_{3}$ & 240.5 & 335.03 & $9.25 \times 10^{5}$ & 0.5153 & 0.48782 & Not Significant \\
$X_{2} X_{4}$ & 214.5 & 335.03 & $7.36 \times 10^{5}$ & 0.4099 & 0.53513 & Not Significant \\
$X_{3} X_{4}$ & -698.75 & 335.03 & $7.81 \times 10^{6}$ & 4.3498 & 0.0611 & Not Significant \\
$X_{1} X_{1}$ & -1078.74 & 431.12 & $1.12 \times 10^{7}$ & 6.2586 & 0.02942 & Significant \\
$X_{2} X_{2}$ & 63.836 & 431.12 & $3.94 \times 10^{4}$ & 0.0219 & 0.8849 & Not Significant \\
$X_{3} X_{3}$ & -100.62 & 431.12 & $9.78 \times 10^{4}$ & 0.0545 & 0.81973 & Not Significant \\
$X_{4} X_{4}$ & 152.55 & 431.12 & $2.25 \times 10^{5}$ & 0.1252 & 0.73014 & Not Significant \\
\hline
\end{tabular}

Figure 8 shows a normal diagram, in which the normality estimate of effects are shown: the statistical significance of both main and interaction factors are easily seen. Significant factors and interactions are evident, because they are far from the line. The slope of the blue line is the same of pseudo standard error, while the red line has a slope equal to 1 . Factor $X_{3}$ has the highest negative effect, but in interaction with factor $X_{1}$ produces a significant positive effect. Other significant factors and interactions are $X_{1}, X_{1} X_{1}, X_{1} X_{3}$, as reported in the mathematical model.

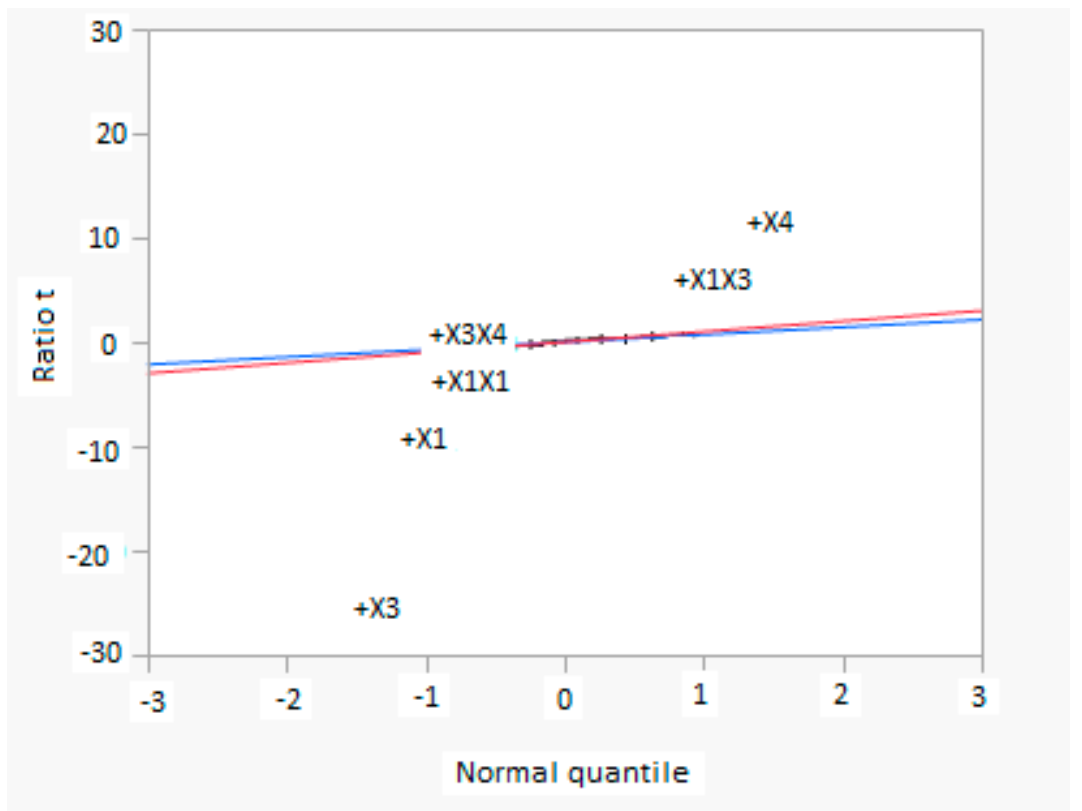

Figure 8. Normal diagram for factors in CCD analysis, considering the methanol production as response $\left(X_{1}=\right.$ reaction temperature in $\mathrm{K}, X_{2}=$ reaction pressure in bar, $X_{3}=\mathrm{H}_{2} / \mathrm{CO}_{2}$ ratio, $X_{4}=$ the recycle of produced stream).

The mathematical model allows to find a response surface plot related to methanol production. Regarding to this, Figure $9 \mathrm{a}, \mathrm{b}$ shows the trend of response surface for the methanol production versus significant main factors. Figure 9 a shows the methanol production versus $X_{1}$ and $X_{3}$, respectively factors $A$ and $C$ : a higher production of methanol is obtained with factor $A$ and $C$ at lower level, as found 
in previous analysis. Figure $9 \mathrm{~b}$ shows the methanol production versus $X_{1}$ and $X_{4}$, respectively factors $A$ and $D$ : a higher methanol production is obtained with factor $A$ at lower level and factor $\mathrm{D}$ at higher level. However, these considerations are not related to the reactor volume, which must be minimized.

The isometric profile in Figure 10a shows optimal operating conditions in order to have the maximum methanol production: a lower level of factors $A$ and $C$ ensures a higher productivity, equal to $37,771 \mathrm{~kg} / \mathrm{h}$.

However, in order to have also a lower reactor volume, according to previous results it is preferable to work with a higher value of factor $A$. In these conditions, the methanol production is equal to $17,888 \mathrm{~kg} / \mathrm{h}$, as shown in Figure 10a. Considering these results and factor $D$ in the isometric profile shown in Figure 10b, the optimal methanol production is obtained for factor $D$ at higher level. Then, optimal conditions are present with factor $A$ at higher level, factor $C$ at lower level, and factor $D$ at higher level. These conditions allow a methanol production equal to $33,540 \mathrm{~kg} / \mathrm{h}$ while the reactor volume is equal to $6 \mathrm{~m}^{3}$.
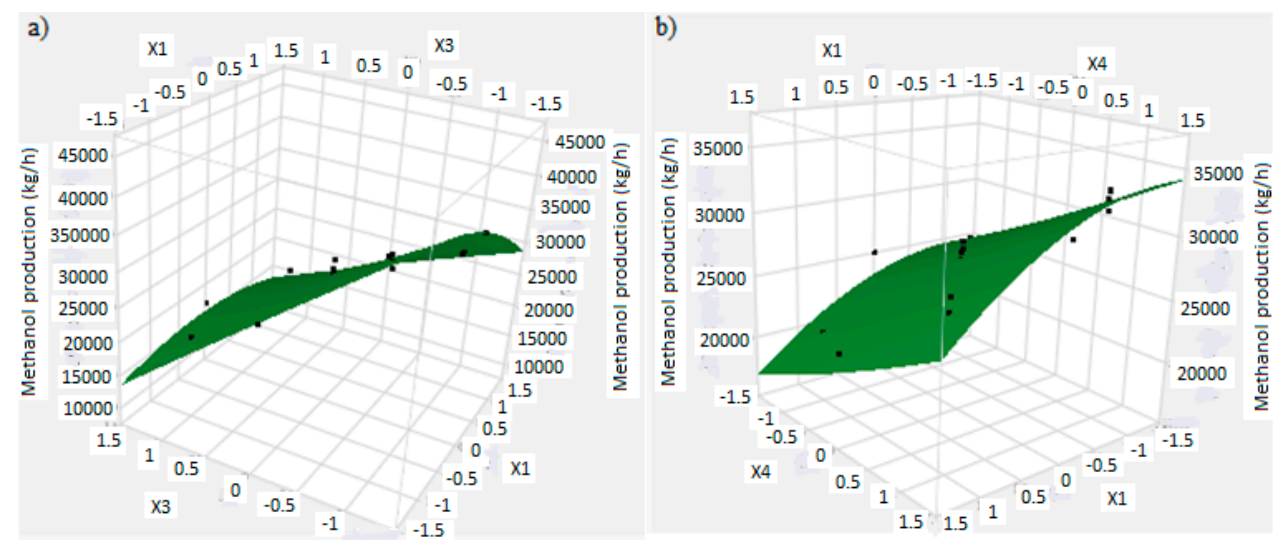

Figure 9. (a) Response surface plot of the methanol production and residues versus factor $X_{1}$ (reaction temperature) and factor $\mathrm{X}_{3}\left(\mathrm{H}_{2} / \mathrm{CO}_{2}\right.$ ratio); (b) Response surface plot of the methanol production and residues versus factor $X_{4}$ (the recycle of produced stream) and factor $X_{1}$ (reaction temperature).
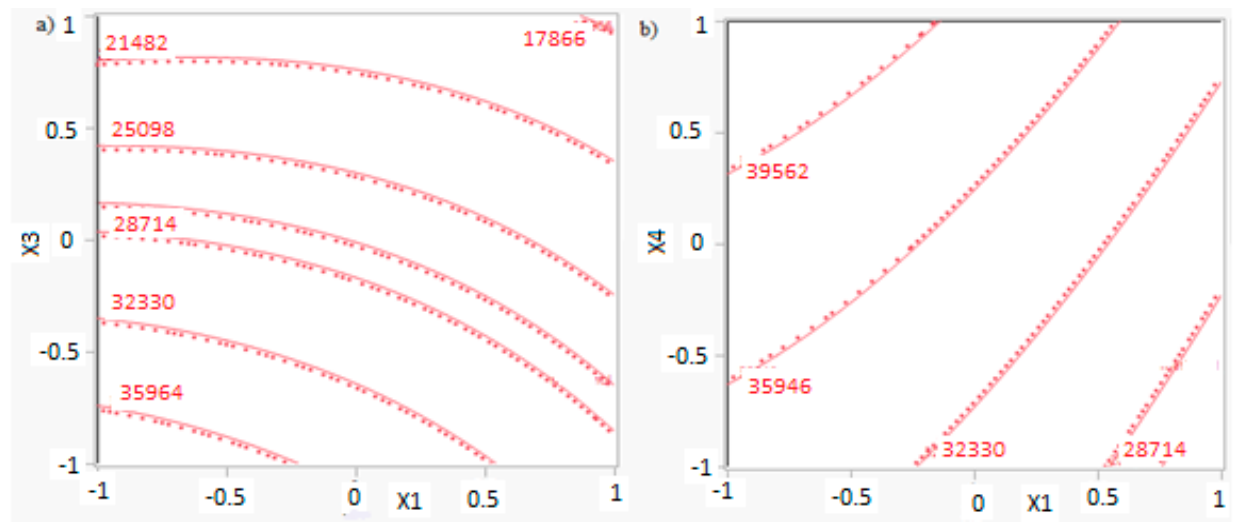

Figure 10. Isometric profile for the methanol production according to (a) factor $X_{1}$ (reaction temperature) and factor $X_{3}\left(\mathrm{H}_{2} / \mathrm{CO}_{2}\right.$ ratio) while factor $X_{4}$ (the recycle of produced stream) is at 0 level; (b) factor $X_{1}$ (reaction temperature) and factor $X_{4}$ (the recycle of produced stream) while factor $X_{3}\left(\mathrm{H}_{2} / \mathrm{CO}_{2}\right.$ ratio $)$ is set at the higher level.

\section{Conclusions}

Carbon capture and utilization (CCU) is presented as a medium-term alternative to mitigate climate change. Carbon dioxide can be used to produce many chemical compounds, such as methanol, methane, syngas, formic acid, and dimethyl ether through hydrogenation reactions. 
Methanol is one of the most valuable chemicals, with a series of uses either as fuel or as building block for the synthesis of other chemicals. Methanol synthesis by the hydrogenation of carbon dioxide is a feasible and efficient process, in an exothermic reaction. Other different raw materials and routes can be used to produce methanol. However, the use of carbon dioxide and hydrogen by renewable energy allows a green process with a lower environmental impact.

In this research, an ANOVA analysis and a central composite design were developed for a reactor producing methanol by the hydrogenation of carbon dioxide. The reactor was modelled in ChemCad $6.3^{\circledR}$ software and simulation results were used for two analyses. The aim of this study was to find the conditions that allow a higher methanol production and a lower reactor volume to be obtained. The kinetics of Graaf were used to describe the methanol production, while $\mathrm{Cu} / \mathrm{ZnO} / \mathrm{Al}_{2} \mathrm{O}_{3}$ was used as catalyst. The kinetic model contains the hydrogenation of $\mathrm{CO}$ and $\mathrm{CO}_{2}$. Major kinetic studies for methanol synthesis were conducted as early as 1977, and even recently researchers have been trying to model the kinetic process. In ANOVA analysis, reaction temperature (factor A), reaction pressure (factor $\mathrm{B}$ ), $\mathrm{H}_{2} / \mathrm{CO}_{2}$ ratio (factor $\mathrm{C}$ ), and the recycle of produced stream (factor $\mathrm{D}$ ) were the chosen factors, while the methanol production and the reactor volume were the analyzed responses. Two different mathematical models for these responses were obtained with significant factors and interactions. Results show that $A C$ is a common interaction, and it allows a higher methanol production to be obtained with a lower reactor volume. In particular, it is preferable to work with factor $A$ at higher level and factor $C$ at lower level. An analysis of residues and a test of the two levels for the significant interactions were also carried out, for a better comprehension of the process. A central composite design was developed in order to find the response surface plot of methanol production: an analysis of four factors with five levels was developed. Optimal conditions were also found: factors $A, C, D$ must be at their higher, lower, and higher levels respectively. In these conditions, the optimal methanol production is equal to $33,540 \mathrm{~kg} / \mathrm{h}$, while the reactor volume is $6 \mathrm{~m}^{3}$. The operative conditions of a catalytic reactor that produces methanol by the hydrogenation of carbon dioxide were then obtained in this research, maximizing the productivity and reducing the costs. A similar work is not present in literature, so the novelty of the study is evident. Future researchers should consider a detailed economic analysis in order to have lower costs. Important considerations were obtained by the developed analysis that can be used for the design of methanol reactors or for the optimization of existing reactors.

Acknowledgments: The author of the study would like to thank the University of L'Aquila for funding this work. Conflicts of Interest: The author declares no conflict of interest.

\section{References}

1. Varone, A.; Ferrari, M. Power to liquid and power to gas: An option for the German Energiewende. Renew. Sustain. Energy Rev. 2015, 45, 207-218. [CrossRef]

2. Kumar, S.; Kwon, H.T.; Choi, K.H.; Cho, J.H.; Lim, W.; Moon, I. Current status and future projections of LNG demand and supplies: A global prospective. Energy Policy 2011, 39, 4097-4104. [CrossRef]

3. Katoch, S.S.; Bhat, I.K. Clean Energy Technology Approaches of Mitigating Greenhouse Gases. Chem. Eng. Trans. 2010, 21, 607-612.

4. Min, J.E.; Lee, Y.J.; Park, H.G.; Zhang, C.; Jun, K.W. Carbon dioxide reforming of methane on Ni-MgO- $\mathrm{Al}_{2} \mathrm{O}_{3}$ catalysts prepared by sol-gel method: Effects of $\mathrm{Mg} / \mathrm{Al}$ ratios. J. Ind. Eng. Chem. 2015, 26, 375-383. [CrossRef]

5. Olah, G.A.; Goeppert, A.; Czaun, M.; Prakash, G.S. Bi-reforming of methane from any source with steam and carbon dioxide exclusively to metgas $\left(\mathrm{CO}-2 \mathrm{H}_{2}\right)$ for methanol and hydrocarbon synthesis. J. Am. Chem. Soc. 2012, 135, 648-650. [CrossRef] [PubMed]

6. Wang, W.; Wang, S.; Ma, X.; Gong, J. Recent advances in catalytic hydrogenation of carbon dioxide. Chem. Soc. Rev. 2011, 40, 3703-3727. [CrossRef] [PubMed]

7. Pérez-Fortes, M.; Schöneberger, J.C.; Boulamanti, A.; Tzimas, E. Methanol synthesis using captured $\mathrm{CO}_{2}$ as raw material: Techno-economic and environmental assessment. Appl. Energy 2016, 161, 718-732. [CrossRef] 
8. Redissi, Y.; Bouallou, C. Valorization of carbon dioxide by co-electrolysis of $\mathrm{CO}_{2} / \mathrm{H}_{2} \mathrm{O}$ at high temperature for syngas production. Energy Proc. 2013, 37, 6667-6678. [CrossRef]

9. Kiss, A.A.; Pragt, J.J.; Vos, H.J.; Bargeman, G.; de Groot, M.T. Novel efficient process for methanol synthesis by $\mathrm{CO}_{2}$ hydrogenation. Chem. Eng. J. 2016, 284, 260-269. [CrossRef]

10. Acar, C.; Dincer, I.; Zamfirescu, C. A review on selected heterogeneous photocatalysts for hydrogen production. Int. J. Energy Res. 2014, 38, 1903-1920. [CrossRef]

11. Jadhav, S.G.; Vaidya, P.D.; Bhanage, B.M.; Joshi, J.B. Catalytic carbon dioxide hydrogenation to methanol: A review of recent studies. Chem. Eng. Res. Des. 2014, 92, 2557-2567. [CrossRef]

12. Van-Dal, E.S.; Bouallou, C. Design and simulation of a methanol production plant from $\mathrm{CO}_{2}$ hydrogenation. J. Clean. Prod. 2013, 57, 38-45. [CrossRef]

13. Riaz, A.; Zahedi, G.; Kleme, J.J. A review of cleaner production methods for the manufacture of methanol. J. Clean. Prod. 2013, 57, 19-37. [CrossRef]

14. Davis, B.H. Overview of reactors for liquid phase Fischer-Tropsch synthesis. Catal. Today 2002, 71, 249-300. [CrossRef]

15. Kathiraser, Y.; Wang, Z.; Kawi, S. Oxidative $\mathrm{CO}_{2}$ reforming of methane in $\mathrm{La}_{0.6} \mathrm{Sr}_{0.4} \mathrm{Co}_{0.8} \mathrm{Ga}_{0.2} \mathrm{O}_{3-\delta}$ (LSCG) hollow fiber membrane reactor. Environ. Sci. Technol. 2013, 47, 14510-14517. [CrossRef] [PubMed]

16. Shi, J.; Shi, F.; Song, N.; Liu, J.-X.; Yang, X.-K.; Jia, Y.-J.; Xiao, Z.-W.; Du, P. Anovel electrolysis cell for $\mathrm{CO}_{2}$ reduction to CO in ionic liquid/organic solvent electrolyte. J. Power Sources 2014, 259, 50-53. [CrossRef]

17. Ahmed, N.; Morikawa, M.; Izumi, Y. Photocatalytic conversion of carbondioxide into methanol using optimized layered double hydroxide catalysts. Catal. Today 2012, 185, 263-269. [CrossRef]

18. Carlesi, C.; Carvajal, D.; Vasquez, D.; Arratia, R.S. Analysis of carbondioxide-to-methanol direct electrochemical conversion mediated by an ionic liquid. Chem. Eng. Process. Process Intensif. 2014, 85, 48-56. [CrossRef]

19. Liu, Y.; Huang, B.; Dai, Y.; Zhang, X.; Qin, X.; Jiang, M.; Whangbo, M.H. Selective ethanol formation from photocatalytic reduction of carbon dioxide in water with $\mathrm{BiVO}_{4}$ photocatalyst. Catal. Commun. 2009, 11, 210-213. [CrossRef]

20. Du, P.; Carneiro, J.T.; Moulijn, J.A.; Mul, G. A novel photocatalytic monolith reactor for multiphase heterogeneous photocatalysis. Appl. Catal. A Gen. 2008, 334, 119-128. [CrossRef]

21. Martín, M.; Grossmann, I.E. Towards zero $\mathrm{CO}_{2}$ emissions in the production of methanol from switchgrass. $\mathrm{CO}_{2}$ to methanol. Comput. Chem. Eng. 2017, 4, 308-318. [CrossRef]

22. Bellotti, D.; Rivarolo, M.; Magistri, L.; Massardo, A.F. Feasibility study of methanol production plant from hydrogen and captured carbon dioxide. J. CO2 Util. 2017, 21, 132-138. [CrossRef]

23. Kang, S.C.; Jun, K.W.; Lee, Y.J. Effects of the $\mathrm{CO} / \mathrm{CO}_{2}$ ratio in synthesis gas on the catalytic behavior in Fischer-Tropsch synthesis using K/Fe-Cu-Al catalysts. Energy Fuel 2013, 27, 6377-6387. [CrossRef]

24. Yao, Y.; Liu, X.; Hildebrandt, D.; Glasser, D. Fischer-Tropsch synthesis using $\mathrm{H}_{2} / \mathrm{CO} / \mathrm{CO}_{2}$ syngas mixtures over an iron catalyst. Ind. Eng. Chem. Res. 2011, 50, 11002-11012. [CrossRef]

25. Johnson, D. Global Methanol Market Review. Available online: http:/ /www.ptq.pemex.com/productosyservicios/ eventosdescargas/Documents/Foro\%20PEMEX\%20Petroqu\%C3\%ADmica/2012/PEMEX_DJohnson.pdf (accessed on 1 June 2012).

26. Biedermann, P.; Grube, T.; Höhlein, B. Methanol as an Energy Carrier. Energy Technology; Forschungszentrum Jülich GmbH: Jülich, Germany, 2006.

27. Kreuer, K.D. On the development of proton conducting polymer membranes for hydrogen and methanol fuel cells. J. Membr. Sci. 2001, 185, 29-39. [CrossRef]

28. Bertau, M.; Offermanns, H.; Plass, L.; Schmidt, F.; Wernicke, H.J. Methanol: The basic Chemical and Energy Feedstock of the Future; Springer-Verlag: Berlin/Heidelberg, Germany, 2014.

29. Olah, G.A. Beyond oil and gas: The methanol economy. Angew. Chem. Int. Ed. 2005, 44, 2636-2639. [CrossRef] [PubMed]

30. Chen, Z.; Yao, M.; Zheng, Z.; Zhang, Q. Experimental and numerical study of methanol/dimethyl ether dual-fuel compound combustion. Energy Fuels 2009, 23, 2719-2730. [CrossRef]

31. Al-Kalbani, H.; Xuan, J.; García, S.; Wang, H. Comparative energetic assessment of methanol production from $\mathrm{CO}_{2}$ : Chemical versus electrochemical process. Appl. Energy 2016, 165, 1-13. [CrossRef]

32. Pérez-Fortes, M.; Tzimas, E. Techno-Economic and Environmental Evaluation of $\mathrm{CO}_{2}$ Utilisation for Fuel Production; JRC Science Hub: ZG Petten, The Netherlands, 2016. [CrossRef] 
33. Gallucci, F.; Paturzo, L.; Basile, A. An experimental study of $\mathrm{CO}_{2}$ hydrogenation into methanol involving a zeolite membrane reactor. Chem. Eng. Process. Process Intensif. 2004, 43, 1029-1036. [CrossRef]

34. An, X.; Li, J.; Zuo, Y.; Zhang, Q.; Wang, D.; Wang, J. A Cu/Zn/Al/Zr fibrous catalyst that is an improved $\mathrm{CO}_{2}$ hydrogenation to methanol catalyst. Catal. Lett. 2007, 118, 264-269. [CrossRef]

35. Quadrelli, E.A.; Centi, G.; Duplan, J.L.; Perathoner, S. Carbon dioxide recycling: Emerging large-scale technologies with industrial potential. ChemSusChem 2011, 4, 1194-1215. [CrossRef] [PubMed]

36. Atsonios, K.; Panopoulos, K.D.; Kakaras, E. Investigation of technical and economic aspects for methanol production through $\mathrm{CO}_{2}$ hydrogenation. Int. J. Hydrog. Energy 2016, 41, 2202-2214. [CrossRef]

37. Rivera-Tinoco, R.; Farran, M.; Bouallou, C.; Aupretre, F.; Valentin, S.; Millet, P.N.; Gameni, J.R. Investigation of power-to-methanol processes coupling electrolytic hydrogen production and catalytic $\mathrm{CO}_{2}$ reduction. Int. J. Hydrog. Energy 2016, 41, 4546-4559. [CrossRef]

38. Uhm, S.; Kim, Y.D. Electrochemical conversion of carbon dioxide in a solid oxide electrolysis cell. Curr. Appl. Phys. 2014, 14, 672-679. [CrossRef]

39. Atsonios, K.; Panopoulos, K.D.; Kakaras, E. Thermocatalytic $\mathrm{CO}_{2}$ hydrogenation for methanol and ethanol production: Process improvements. Int. J. Hydrog. Energy 2016, 41, 792-806. [CrossRef]

40. Harp, G.; Harp, K.; Tran, C.; Bergins, C.; Buddenberg, T.; Drach, I.; Koytsoumpa, E.I.; Sigurbjornsson, O. Application of Power to Methanol Technology to Integrated Steel works for Profitability, Conversion Efficiency, and $\mathrm{CO}_{2}$ Reduction. In Proceedings of the 2nd European Steel Technology and Application Days, Duesseldorf, Germany, 15-19 June 2015.

41. Adam, J.; Harp, G. LOCIMAP Low carbon industrial manufacturing park-potential for symbiosis between Steel and Chemical industry on lowering $\mathrm{CO}_{2}$ emissions 2014. In Proceedings of the European Steel Environment Energy Congress, Teeside, UK, 15-17 September 2014.

42. Pedersen, T.H.; Schultz, R.H. Technical and Economic Assessment of Methanol Production from Biogas. Master's Thesis, University of Aalborg, Aalborg, Denmark, 31 May 2012.

43. Matzen, M.J. Sustainability Assessment for Energy Systems and Chemical Process Industries. Master's Thesis, University of Nebraska-Lincoln, Department of Chemical and Biomolecular Engineering, Lincoln, NE, USA, December 2015.

44. Gai, S.; Yu, J.; Yu, H.; Eagle, J.; Zhao, H.; Lucas, J.; Doroodchi, E.; Moghtaderi, B. Process simulation of a near-zero-carbon-emission power plant using $\mathrm{CO}_{2}$ as the renewable energy storage medium. Int. J. Greenh. Gas Control 2016, 47, 240-249. [CrossRef]

45. Graaf, G.H.; Stamhuis, E.J.; Beenackers, A.A.C.M. Kinetics of low pressure methanol synthesis. Chem. Eng. Sci. 1988, 43, 3185-3195. [CrossRef]

46. Mignard, D.; Pritchard, C. Processes for the synthesis of liquid fuels from $\mathrm{CO}_{2}$ and marine energy. Chem. Eng. Res. Des. 2006, 84, 828-836. [CrossRef]

47. Mignard, D.; Sahibzada, M.; Duthie, J.M.; Whittington, H.W. Methanol synthesis from flue-gas $\mathrm{CO}_{2}$ and renewable electricity: A feasibility study. Int. J. Hydrog. Energy 2003, 28, 455-464. [CrossRef]

48. Anicic, B.; Trop, P.; Goricanec, D. Comparison between two methods of methanol production from carbon dioxide. Energy 2014, 77, 279-288. [CrossRef]

49. Pontzen, F.; Liebner, W.; Gronemann, V.; Rothaemel, M.; Ahlers, B. $\mathrm{CO}_{2}$-based methanol and DME e efficient technologies for industrial scale production. Catal. Today 2011, 171, 242-250. [CrossRef]

50. Wilkinson, S.K.; van de Water, L.G.A.; Miller, B.; Simmons, M.J.H.; Stitt, E.H.; Watson, M.J. Understanding the generation of methanol synthesis and water gas shift activity over copper-based catalysts-A spatially resolved experimental kinetic study using steady and non-steady state operation under $\mathrm{CO} / \mathrm{CO}_{2} / \mathrm{H}_{2}$ feeds. J. Catal. 2016, 337, 208-220. [CrossRef]

51. Zoulias, E.; Varkaraki, E.; Lymberopoulos, N.; Christodoulou, C.N.; Karagiorgis, G.N. A review on water electrolysis. TCJST 2004, 4, 41-71.

52. Dutta, A.; Dowe, N.; Ibsen, K.N. An economic comparison of different fermentation configurations to convert corn stover to ethanol using Z. mobilis and Saccharomyces. Biotechnol. Prog. 2009, 26, 64-72.

53. Montgomery, D.C. Design and Analysis of Experiments; John Wiley \& Sons: New York, NY, USA, 2005.

54. Dutka, B.M.; Ditaranto, M.; Løvås, T. Application of a Central Composite Design for the Study of NOx Emission Performance of a Low NOx Burner. Energies 2015, 8, 3606-3627. [CrossRef]

55. Bas, D.; Boyaci, I.H. Modeling and optimization I: Usability of response surface methodology. J. Food Eng. 2007, 78, 836-845. [CrossRef] 
56. Box, G.E.P.; Hunter, J.S.; Hunter, W.G. Statistics for Experimenters: Design, Innovation, and Discovery; Wiley-Interscience: Hoboken, NJ, USA, 2005; pp. 447-455.

57. Khamparia, S.; Jaspal, D. Study of decolorisation of binary dye mixture by response surface methodology. J. Environ. Manag. 2017, 201, 316-326. [CrossRef] [PubMed]

58. Rahman, D. Kinetic Modeling of Methanol Synthesis From Carbon Monoxide, Carbon Dioxide, and Hydrogen Over A Cu/ZnO/ $\mathrm{Cr}_{2} \mathrm{O}_{3}$ Catalyst. Master's Thesis, San Jose State University, San Jose, CA, USA, 2012.

59. Xin, A.N.; Yizan, Z.; Qiang, Z.; Jinfu, W. Methanol synthesis from $\mathrm{CO}_{2}$ hydrogenation with a $\mathrm{Cu} / \mathrm{Zn} / \mathrm{Al} / \mathrm{Zr}$ fibrous catalyst. Chin. J. Chem. Eng. 2009, 17, 88-94.

60. Yang, R.; Yu, X.; Zhang, Y.; Li, W.; Tsubaki, N. A new method of low-temperature methanol synthesis on $\mathrm{Cu} / \mathrm{ZnO} / \mathrm{Al}_{2} \mathrm{O}_{3}$ catalysts from $\mathrm{CO} / \mathrm{CO}_{2} / \mathrm{H}_{2}$. Fuel 2008, 87, 443-450. [CrossRef]

61. Shen, W.J.; Jun, K.W.; Choi, H.S.; Lee, K.W. Thermodynamic Investigation of Methanol and Dimethyl Ether Synthesis from $\mathrm{CO}_{2}$ Hydrogenation. Korean J. Chem. Eng. 2000, 17, 210-216. [CrossRef]

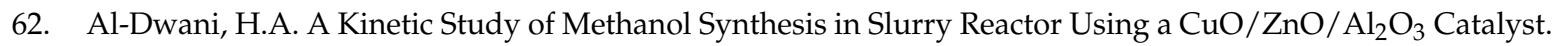
Master's Thesis, Texas\&M University, College Station, TX, USA, 1992.

63. Park, N.; Park, M.J.; Ha, K.S.; Lee, Y.J.; Jun, K.W. Modeling and analysis of a methanol synthesis process using a mixed reforming reactor: Perspective on methanol production and $\mathrm{CO}_{2}$ utilization. Fuel 2014, 129, 163-172. [CrossRef]

64. Fogler, H.S. Elements of Chemical Reaction Engineering, 4th ed.; Prentice Hall: Upper Saddle River, NJ, USA, 2004.

(C) 2017 by the author. Licensee MDPI, Basel, Switzerland. This article is an open access article distributed under the terms and conditions of the Creative Commons Attribution (CC BY) license (http:/ / creativecommons.org/licenses/by/4.0/). 